\title{
Review \\ The Tumor Microenvironment in Follicular Lymphoma: Its Pro-Malignancy Role with Therapeutic Potential
}

\author{
Takashi Watanabe
}

check for updates

Citation: Watanabe, T. The Tumor Microenvironment in Follicular Lymphoma: Its Pro-Malignancy Role with Therapeutic Potential. Int. J. Mol. Sci. 2021, 22, 5352. https://doi.org/ $10.3390 /$ ijms 22105352

Academic Editor: Lukas

J.A.C. Hawinkels

Received: 4 April 2021

Accepted: 12 May 2021

Published: 19 May 2021

Publisher's Note: MDPI stays neutral with regard to jurisdictional claims in published maps and institutional affiliations.

Copyright: (C) 2021 by the author. Licensee MDPI, Basel, Switzerland. This article is an open access article distributed under the terms and conditions of the Creative Commons Attribution (CC BY) license (https:// creativecommons.org/licenses/by/ $4.0 /)$.
Department of Personalized Cancer Immunotherapy, Mie University Graduate School of Medicine, 2-174, Edobashi, Tsu City, Mie 514-8507, Japan; twatanabe@med.mie-u.ac.jp

\begin{abstract}
In the follicular lymphoma (FL) microenvironment, $\mathrm{CXCR} 5^{+} \mathrm{ICOS}^{+} \mathrm{PD} 1^{+} \mathrm{BCL6}{ }^{+}$follicular helper T (Tfh) cells, which closely correlate with FL B cells in neoplastic follicles, play a major role in supporting FL. Interleukin-4 secreted by Tfh cells triggers the upregulation of the lymphocyte chemoattractant CXCL12 in stromal cell precursors, in particular by fibroblastic reticular cells (FRCs). In turn, mesenchymal stem cells (MSCs) can be committed to FRC differentiation in the bone marrow and lymph nodes involved by FL. Noteworthy, MSCs can promote the differentiation of Tfh cells into highly immunosuppressive T-follicular regulatory cells. The tumor suppressor HVEM is highly mutated in FL cells, and its deficiency increases Tfh cell frequency. In contrast, PI3K $\delta$ inhibition impedes the recruitment of $\mathrm{Tfh} /$ regulatory $\mathrm{T}$ cells and impairs the proliferation of follicular dendritic cells (FDCs) and FDC-induced angiogenesis. Since TIGIT ligands are expressed by FDCs, the immune checkpoint receptor TIGIT plays an important role in tumor-infiltrating T cells. Thus, TIGIT blockade might invigorate cytotoxic T cells in the FL microenvironment. Given their potential to simultaneously reduce the neoplastic B cells, Tfh, and TFR cells could also reinforce the effects of the cytotoxic T cells. This combinatory strategy should be explored as a treatment option to tackle FL.
\end{abstract}

Keywords: follicular lymphoma; microenvironment; follicular helper T cell (Tfh); fibroblastic reticular cell (FRC); follicular dendritic cell (FDC); HVEM/TNFRSF14; T-follicular regulatory cell (TFR); idelalisib; EZH2; TIGIT

\section{Introduction}

Follicular lymphoma (FL) is the second most common B-cell non-Hodgkin lymphoma (B-NHL), and patients with FL commonly experience a slowly progressive disease. Given its indolent course, approximately $80 \%$ of patients already have advanced FL at the initial diagnosis. Patients with FL show a variable clinical path even without treatment, with spontaneous remissions being reported in up to $15 \%$ of the patients. Nevertheless, half of FL patients have histologically transformed diseases to aggressive lymphoma and finally succumb to the disease. A variety of treatment strategies for FL are currently used in the clinic, including observation without any treatment (so-called watchful waiting), rituximab alone, the anticluster of differentiation (CD)20 antibody combined with monotherapy or a combination of chemotherapy, radiotherapy in the case of limited disease, radioimmunotherapy (an anti-CD20 antibody conjugated with radioisotope), and high-dose chemotherapy followed by hematopoietic stem cell transplantation. Recently, the cumulative incidence of FL was reduced from $28-45 \%$ [1,2] to $9.3 \%$ at 10 years as a result of long-term observation following immunochemotherapy with the anti-CD20 antibody rituximab combined with chemotherapy [3].

Histopathology of FL is characterized by the formation of neoplastic follicles, which resemble the normal lymph node (LN) architecture. Many non-tumor cells surround the neoplastic cells in the FL LNs, some of which contribute to lymphomagenesis, including LN stromal cells, T-follicular helper cells (Tfh), T-follicular regulatory cells (TFRs), and follicular dendritic cells (FDCs). The correlation between macrophage infiltration in FL LNs and patient prognosis remains controversial, but might vary according to the use of rituximab or 
different chemotherapeutic regimens [4]. In particular, a doxorubicin-containing regimen has been suggested to abolish the negative effect of $\mathrm{CD} 163^{+}$tumor-associated macrophages (TAMs) [4]. As for T cells, intratumoral T cells in FL LNs are heterogeneous depending on the prevalence of various T-cell subpopulations and location of the cells in relation to the follicles. For example, patients with intrafollicular or perifollicular (in a follicular pattern) forkhead box protein 3 (FoxP3) ${ }^{+}$cells have a significantly higher risk of histologic transformation and shorter survival than those with FoxP3 $3^{+}$cells scattered in a diffuse pattern [5]. In contrast, high numbers of tumor-infiltrating $\mathrm{FoxP}^{+}$cells are related to improved overall survival (OS) in FL [6].

Programmed cell death-1 (PD-1) is a well-known T-cell exhaustion marker, but two distinct T-cell subpopulations with PD-1 expression were identified in FL. The intratumoral $\mathrm{CD} 4^{+} \mathrm{PD}-1^{\text {high }} \mathrm{T}$ cells, which have a Th phenotype, express the $\mathrm{C}-\mathrm{X}-\mathrm{C}$ chemokine receptor type 5 (CXCR5), secrete interleukin (IL)-21, and are B-cell lymphoma 6 (BCL6) positive, but do not express the T-cell immunoglobulin and mucin domain-containing protein 3 (TIM-3), and support B-cell growth. In turn, the $\mathrm{CD} 4^{+} \mathrm{PD}-1^{\text {low }} \mathrm{T}$ cells, which have an exhausted phenotype, express TIM-3 and do not express either BCL6 or CXCR5 (Figure 1) [7]. Furthermore, T cells infiltrated in the FL LN are not simply exhausted, and there are other reasons contributing to their tolerogenic function.

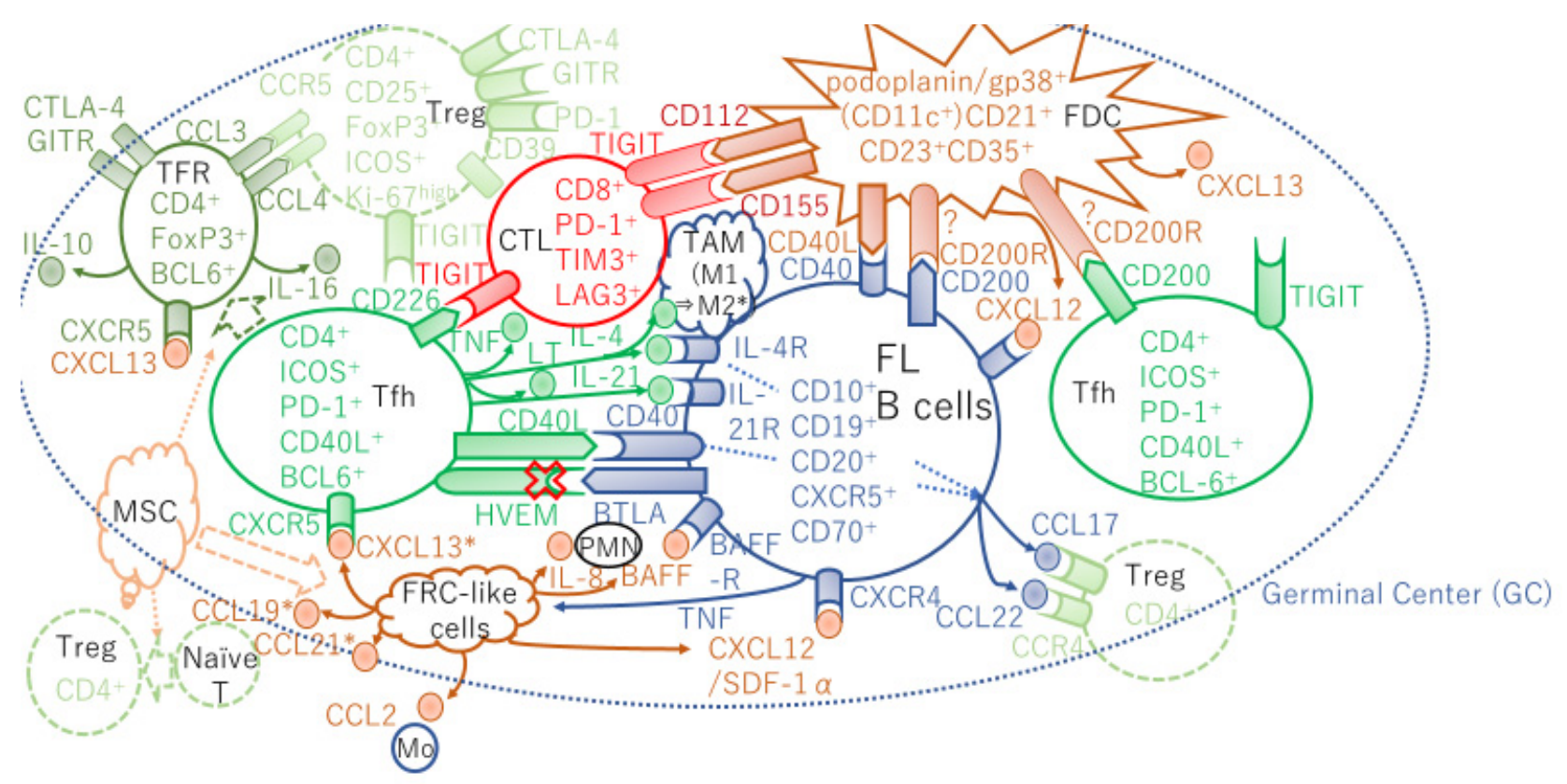

Figure 1. Lymphoid stromal cells and $\mathrm{CD}^{+} \mathrm{T}$ cells supporting FL B-cell growth and allowing escape from immune surveillance with cytokine/chemokine circuits in the GC. The disruption of inhibitory signals delivered to the BTLA receptor increases Tfh. HVEM loss trigger production of TNF family cytokines that activate the lymphoid stroma cells; FDCs and FRCs. FRC-like cells produce CCL19 and CXCL13 that recruits CXCR5 ${ }^{+} \mathrm{Tfh}$. In turn, Tfh produce IL-4 and IL-21 providing mitogenic signals to FL B cells. TFRs produce CCL3 (MIP-1 $\alpha$ ) and CCL4 (MIP-1 $\beta$ ) are chemotactic for Tregs. ${ }^{*}$ TAM polarization by IL-4 [8] and CXCL13, CCL19, and CCL21 secreted by normal FRCs [9] were results from mice experiments. In mice, TFRs originate from naïve Tregs [10-12]. In contrast, human FL TFRs in part originate from Tfh cells [13]. CD200R was found to be expressed just on classical DC (CD11c $\left.{ }^{+} \mathrm{HLA}_{-} \mathrm{DR}^{+}\right)$from FL LNs. PMN, polymorphonuclear neutrophil; Mo, monocyte. Details in the text.

The purpose of this review article is to clarify the peculiar abnormal players in the FL LN compared with their normal counterparts in healthy LNs, with focus on LN stromal cells, especially fibroblastic reticular cells (FRCs), FDCs, Tfh cells, and TFRs. Approaches to invigorate dysfunctional $\mathrm{CD}^{+} \mathrm{T}$ cells combined with those to dampen lymphomasupporting $\mathrm{CD}^{+}{ }^{+} \mathrm{T}$ cells, if any, and stromal cells are an ideal armament to tackle the incurable FL. 


\section{Heterogeneity of Lymphoid Stromal Cells}

FRCs produce and ensheath collagen bundles and other extracellular matrix constituents, organizing an enclosed conduit system that is engaged in the delivery of small molecules, including chemokines and antigens, to the T-cell zone in lymphoid organs. In mice, FRCs express the B-cell-survival factor and T-cell-costimulator B-cell-activating factor belonging to the tumor necrosis factor (TNF) family (BAFF). They produce large amounts of transcripts of the CC chemokine ligand (CCL) 19 and CCL21, and of the C-X-C motif chemokine (CXCL)13, a B-cell chemoattractant restricted to FDCs [9]. FRCs transcribe other chemokines, including CCL2 and CCL7, which promote the recruitment or organization of receptor-expressing memory T cells and dendritic cells (DCs). Moreover, FRCs are the main source of the lymphocyte chemoattractant CXCL12, also known as stromal cell-derived factor 1 (SDF-1 $\alpha$ ) [9], and are found in the vicinity of T cells, contributing for their recruitment and dynamic motion along cytoplasmic extensions that function as guide paths. Several studies have reported prominent effects of FRCs on T cell survival [14].

At the earliest stage of germinal center (GC) response, both Tfh cells and a specific FRC subset producing a proliferation-inducing ligand (APRIL) are implicated in the generation of plasmablasts at the GC-T zone interface before terminal maturation into plasma cells [15]. FRCs undergo massive morphological shifts and proliferative expansion to adapt to the increase in $\mathrm{B}$ and $\mathrm{T}$ lymphocyte numbers, and these alterations trigger the glycoprotein 38/podoplanin (PDPN) on FRCs by C-type lectin-like receptor 2 expression on DCs, leading to reduced FRC contractility [16]. FRCs are also implicated in peripheral immune tolerance, supporting tolerance toward $\mathrm{CD}^{+}$and $\mathrm{CD}^{+} \mathrm{T}$ cells via direct antigen presentation [17] and limiting the proliferation of activated $\mathrm{T}$ cells independently of antigen presentation [17]. In mice, this suppressive function was ascribed to the expression of inducible nitric oxide synthase [18], whereas in humans, FRCs compel suppression through a combination of several mechanisms such as indoleamine-2,3-dioxigenase, prostaglandin E2 (PGE2), transforming growth factor- $\beta$ receptor, and adenosine $2 \mathrm{~A}$ receptor (A2AR) signaling in secondary lymphoid organs [19]. Indoleamine-2,3-dioxigenase oxidizes tryptophan to kynurenine metabolites, which take away tryptophan from effector T cells, leading to proliferative arrest and exposing them to immunosuppressive kynurenine, thereby impairing T-cell growth and survival [20]. In humans, PGE2 is the most abundant member of the prostanoid family, which is secreted by professional antigen-presenting cells and stromal cells [21]. PGE2 induces a suppressive phenotype in non-regulatory $\mathrm{CD} 4^{+} \mathrm{T}$ cells that can suppress the proliferation of other T cells undergoing activation [22]. Adenosine generation is induced during inflammation and in low-oxygen-tension microenvironments, and A2AR activation elevates intracellular cyclic adenosine monophosphate, which inhibits cytokine responses. Consequently, A2AR repression induces tumor-reactive $\mathrm{CD} 8^{+} \mathrm{T}$ cells in mouse models [23].

Misiak et al. recently showed that FRC-like cells enhance the growth of the entire CXCR5 ${ }^{+} \mathrm{CD}_{4}^{+}$T-cell compartment, thereby promoting IL-4 production specifically by the PD $1^{\mathrm{dim}} \mathrm{CXCR}^{+} \mathrm{CD}^{+}$cell subset, in a Notch and intercellular adhesion molecule 1 (ICAM-1)/lymphocyte function-associated antigen-1 (LFA-1)-dependent manner [24]. Analysis of the gene expression profile of FRC-like cells compared with tonsil stromal cells revealed that ICAM-1 was the most upregulated gene and was highly expressed in FRC-like cell membranes [24]. In mice, ICAM-1 bound to LFA-1 controls Tfh production and maintenance and is involved in the generation of Tfh during helminth infection [25]. ICAM1/LFA-1 pathway in IL-4 overexpression of the cells that correspond to Tfh precursor cells in contact with FRC-like cells [24].

T-cell zone reticular cells (TRCs) are predominant in the paracortex, defining the T-cell zone of LNs and producing the homeostatic chemokines CXCL19 and CCL21 to mediate the recruitment and interaction of $\mathrm{C}-\mathrm{C}$ chemokine receptor type 7 (CCR7)-expressing naïve $\mathrm{T}$ cells and DCs. TRCs keep naïve T cells alive by secreting IL-7 and CCL19 [14].

Marginal reticular cells (MRCs) reside at the edge of the follicle, underneath the subcapsular sinus. A subset of non-FDC CD21-lineage cells are dormant stromal cells that 
can be converted into CXCL13-secreting cells upon contact with activated B cells of the growing follicles and are called versatile stromal cells [26].

Dark zone CXCL12-expressing reticular cells (CRCs) share with FDCs a high expression of the transcription factor SRX-related HMG-box 9 [27,28]. CRCs are involved in the recruitment of CXCR4 ${ }^{\text {high }}$ centroblastic B cells in the dark zone, the pole of the GC closest to the T-cell zone.

Medullary FRCs (MedRC) form the major structural components of the plasma cell niche within LN medullary cords [29]. Preadipocytic precursors differentiate into several lymphoid stromal cell subsets, including MRCs and FRCs [30]. Perivascular cells have been proposed as precursors of lymphoid stromal cell subsets, including PDPN/gp38 ${ }^{-} \mathrm{CD} 31^{-}$ mural cells (pericytes) expressing smooth muscle actin, platelet-derived growth factor receptor, beta polypeptide, and PDPN $/ g \mathrm{gp} 38^{+} \mathrm{CD} 34^{+}$adventitial cells [31]. Notably, splenic and LN stromal cells appear to rely on different developmental mechanisms and tissuespecific progenitors [32]. MedRCs generate different extracellular matrix structure than TRCs and specifically produce high amount of CXCL12, BAFF, APRIL, and IL-6. They guide the migration of $\mathrm{CXCR} 4^{+}$plasma cell within the medulla and contribute to plasma cell survival in situ together with medullary macrophages [29].

\section{Follicular Dendritic Cell Role in Healthy and Neoplastic Follicles}

FDCs and macrophages are fundamental components of FL pathogenesis [33,34]. Chevalier et al. [35] found that neoplastic follicles included lower DCs and higher regulatory $\mathrm{T}$ cell (Treg) frequencies than hyperplastic follicles in control LNs. Treg numbers correlated with the subset of conventional CD11 $\mathrm{c}^{+} \mathrm{DCs}$, suggesting that the presence of $\mathrm{CD}_{11 \mathrm{c}^{+}} \mathrm{DC}$ s in the tumor microenvironment may assist tumor infiltration by Tregs [35]. In case of predominantly diffuse growth pattern of FL, mature PDPN $/ g p 38^{\text {high }} \mathrm{CCL} 21^{+}$ FDCs have been shown to progressively disappear from FL LN, in agreement with the strongly reduced lymphotoxin- $\alpha 1 \beta 2$ (LT) production in FL B cells compared with normal GC B cells [36].

In the rituximab era, only few studies have focused on the role of the tumor microenvironment in the transformation of FL. These studies used gene expression profiling or immunohistochemistry to assess the relation between molecular markers in the tumor microenvironment and the time to transformation (TTT). Blaker et al. [37] analyzed paired specimens of FL and transformed FL (tFL) biopsies and compared the cohort with tFL to an independent cohort of FL patients without signs of transformation. Better CD21 $1^{+}$FDC meshwork at diagnosis was correlated with shorter OS, progression-free survival (PFS), and TTT in tFL patients treated with rituximab. In addition, the remaining FDC meshworks at transformation were associated with shorter OS and PFS from transformation [37].

Moreover, Ohe et al. [38] analyzed the localization of collagen-modifying enzymes on FRCs and FDCs, revealing that the expression of prolyl 4-hydroxylase 1, lysyl hydroxylase 3 , and protein disulfide isomerase was often found in FRCs and FDCs in GC in nonneoplastic lymphoid tissues. However, the expression of the collagen-modifying enzymes was lower in most examined lymphomas than in their normal counterparts, and the ratio of transglutaminase (TG) $\mathrm{II}^{+}$FRCs $/ \mathrm{CD} 35^{+}$FDCs was lower in FL [38]. Interestingly, the same research group found that the proportion of estrogen receptor $\alpha$ on FDCs was higher, along with a larger $\mathrm{CD}_{23}{ }^{+}$FDC meshwork, in Grade 1-2 FL than in Grade 3 FL [39]. Similarly, another group reported that Grade 3 FL exhibited a significant decrease of CD23 expression by the FDCs as compared with G1 FL, although CD21 expression was not significantly different [40]. Furthermore, Ohe et al. reported that high estrogen receptor $\alpha$ expression on FDCs was an independent prognostic factor for OS and PFS in FL patients [41].

Recently, it was shown that FDC-induced genes are relevant to angiogenesis, extracellular matrix formation, and transendothelial migration in a subset of FL samples. The phosphatidylinositol 3-kinase $\delta$ isoform inhibitor idelalisib, which was approved for relapsed or refractory (R/R) FL by the U.S. Food and Drug Administration [42], reduced FDC-induced angiogenesis and migration, interference with the FL B-T immunological 
synapses via CD40/CD40 ligand (CD40L) axis, and affected Treg and Tfh recruitment through CCL22 downregulation [43]. Idelalisib induced the simultaneous reduction of integrins and their ligands in responders, indicating a reduction in the transendothelial migration capability [43]. The CD40/CD40L pathway lies on the crosstalk between B and $\mathrm{T}$ cells in the GC and is necessary for B-cell survival, proliferation, and differentiation into plasma cells. Idelasilib inhibits the proliferation of FDCs that overexpress CD40L on their cell membranes, and it decreases the expression of ICAM-1 or CD80, all of which are directly involved in B-T immunological synapses. Moreover, idelalisib decreases the expression of CCL22 secreted in the FL-FDC niche, which is the ligand for the CCR4 receptor expressed on Tregs [43].

Although the B-cell lymphoma 2 (BCL2) inhibitor venetoclax showed limited activity in FL [44], a recovery of venetoclax activity was observed in coculture with FL-FDCs or FL-macrophages when treated with idelalisib, by restoring BCL2 dependence over B-cell lymphoma-extra large (BCL- $\mathrm{X}_{\mathrm{L}}$ ) and myeloid cell leukemia-1 or BCL2-related protein A1, respectively [43]. Collectively, combination therapy of anti-B-cell targeting agents with idelalisib, a FL microenvironment modulator should be explored.

Interestingly, digital image analysis of the distribution of bystander cells within follicles of FL revealed that, whereas B cells and macrophages display complete spatial randomness, all T cells, Tfh (identified by PD-1), and DCs (identified by CD21) clustered within a radius of $6-10 \mu \mathrm{m}$ [45].

A couple of studies providing disruption strategies of FDCs-FL cell crosstalk were reported in vitro. The previous study indicated that FL cells having cancer stem cell-like activities interacted with FDCs in a CXCL12/CXCR4 dependent manner, including resistance to cyclophosphamide or doxorubicin, in vitro and in NOD/Scid mice and that a specific CXCL12/CXCR4 inhibitor exhibited tumor growth [46]. Furthermore, PI3K inhibitors can be one of the candidate drugs combined with antineoplastic $B$ cell agents because a panPI3K inhibitor showed counteractions against angiogenesis, cell adhesion, migration, and "serum-like responses" (namely, cell survival and proliferation [47]) activated by FDCs [48]. However, there is no information on the selective PI3K $\delta$ isoform inhibitor idelalisib against these activities. There have been no reports concerning targeting FDCs-FL interaction since 2015 either.

\section{Mesenchymal Stem Cells Orchestrate the FL Cell Niche and Cancer-Associated Fibroblasts in the FL Microenvironment}

Cancer-associated fibroblasts (CAFs) are phenotypically and functionally different from their normal counterparts, presenting a niche-based model of oncogenesis attributed to the dynamic coevolution of both cancer and stromal cells. Mesenchymal stem cells (MSCs) can be recruited within tumors, where they are integrated into the stroma, become activated, and augment tumor growth. LN containing bona fide MSCs, human bone marrow (BM)-MSCs, and LN-MSCs can be committed to FRC differentiation in response to a combination of TNF- $\alpha$ and LT, the two main factors implicated in the differentiation and sustenance of secondary lymphoid organs. Mesenchymal cells recruit malignant B cells and protect them from spontaneous and drug-induced cell death [49,50]. LT and TNF- $\alpha$ are two non-redundant key factors involved in lymphoma stromal cell differentiation and maintenance. B cells contribute to FRC activation and maintenance in both LN and spleen through their inducible expression of LT [32,51,52].

MSCs was shown to induce the differentiation of naïve T-cells to Tregs, thereby contributing for the modulation of the FL biology [53]. Thus, MSCs were proposed as organizers of the FL cell niche. MSCs overexpress CCL2, which recruit monocytes. Monocytes are further changed into proangiogenic and anti-inflammatory macrophages [54]. In particular, FL B cells can trigger the commitment of MSCs to differentiation into an FRClike phenotype, and for MSCs to overexpress CCL2 and IL-8 in a TNF-dependent manner, resulting in FRC meshwork activation within involved LN and BM $[49,54,55]$. Furthermore,

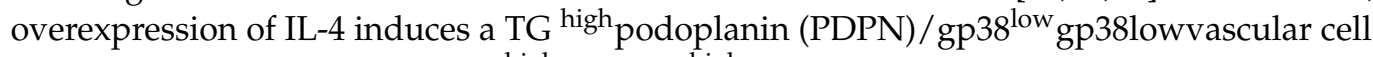
adhesion molecule-1 (VCAM-1) ${ }^{\text {high }}$ CXCL12 ${ }^{\text {high }}$ phenotype in human mesenchymal pro- 
genitors and FRC-like cells, a profile that resembles that identified in situ within the FL cell niche [56]. Additionally, TNF- $\alpha / \mathrm{LT}$ and IL-4 induced the construction of an extracellular TG-positive meshwork. Whereas TNF- $\alpha /$ LT decreased TG mRNA, IL-4 induced both TG expression and redistribution at the surface of stromal cells [56]. Additionally, TNF/LT and IL-4 can induce the construction of an extracellular TG ${ }^{+}$meshwork [56].

The upregulation of CXCL12 from FL-CAFs in FL-infiltrating LN and BM contributes to the migration, adhesion, and activation of FL B cells with a CXCR4 $4^{+}$phenotype [56] (Figure 1). BM obtained from FL patients with BM involvement revealed CD20 $0^{+}$FL B-cell aggregates with paratrabecular localization, which is characteristic of BM involvement of FL. These B-cell-infiltrated regions exhibited elevated CXCL12 expression compared with outside regions of FL infiltration [6]. FL B cells secrete TNF- $\alpha$, previously involved in the induction of both CCL2 and IL-8 production by BM-MSCs [54,55]. Stromal cells cocultured with TNF ${ }^{\text {high }}$ malignant B cells induced a decrease in CXCL12 expression. Conversely, purified $\mathrm{CD} 4^{+}$CXCR5 ${ }^{\text {high }}$ PD-1 ${ }^{\text {high }}$ FL-Tfh cells induced elevation of CXCL12 in adipose tissue-derived stroma cells [56].

The specific downregulation of LT in FL B cells combined with upregulation of CXCL12 in FL-CAFs suggest a CRC-like origin of at least some FL stromal cells since dark zone CRCs, unlike FRCs and versatile cells, do not require LT and TNF- $\alpha$ to maintain CXCL12 expression and the network morphology [27]. Cultured FL BM stromal cells retained numerous features of their native counterparts, including the overexpression of CCL2, IL-8, and CXCL12, suggesting an imprinting of the stromal cells by the tumor context [54-56].

Autologous CAFs or the stromal cell line HS- 5 were found to protect primary FL cells from apoptosis in response to the BCL2 inhibitor ABT-737 through mRNA induction of the adenosine triphosphate-binding cassette ( $\mathrm{ABC}$ )-drug transporter genes $A B C$ subfamily $C$ member 1 ( $A B C C 1$ ) and $A B C$ sub-family $G$ member 2 ( $A B C G 2$ ), and upregulation of $B C L$ $X_{L}$ [57]. Furthermore, Sakamoto et al. demonstrated that pyruvate secreted from patientderived CAFs supported the survival of primary FL cells [58].

\section{Follicular Helper T Cells}

Unlike other helper T-cell compartments, follicular $\mathrm{CD}^{+} \mathrm{T}$ cells have been defined by their localization in secondary lymphoid organs at the T/B border or within B-cell follicles. Human Tfh cells are defined by the expression of the chemokine receptor CXCR5, the inducible T-cell co-stimulator (ICOS), and PD-1. Tfh cells express the transcription repressor BCL6 (Figure 1) (Table 1), and support the survival and differentiation of normal GC B cells [59]. The Tfh cell compartment comprises a greater proportion of $\mathrm{CD}^{+} \mathrm{T}$ cells in the FL LNs than in normal LNs [60]. Ame-Thomas et al. demonstrated that Tfh cells support FL B-cell viability through the secretion of IL-4 and the expression of CD40L [60]. Moreover, intratumoral Tfh cells expressing IL-4 and CD40L can also induce the production of CCL17 and CCL22 by FL cells (Figure 1), thereby promoting the active migration of Tregs (Figure 1 ) and IL-4 producing CD4 $4^{+} \mathrm{T}$ cells. Furthermore, IL- 4 considerably enhanced phosphorylation of signal transducer and activator of transcription 6 (p-STAT6) in primary FL cells [61]. In fact, Pangault et al. demonstrated that the majority of p-STAT6 ${ }^{+}$B cells were localized in close proximity to the cells that expressed PD-1 ${ }^{+}$(Tfh) [62]. Additionally, it was recently demonstrated that $\mathrm{PD}-1^{+} \mathrm{ICOS}^{+}$Tfh cells and proliferating Ki- $67^{+}$tumor cells are in close contact, and that immune synapses are formed in FL [63]. Moreover, immunohistochemistry studies of FL LNs revealed purified CD $4^{+} C X C R 5^{\text {high }}$ PD- 1 high $\mathrm{Tfh}$ cells, which produced IL-4 and triggered an upregulation of CXCL12 in adipose-derived stromal cells. This IL-4/CXCL12 loop can be magnified in activated lymphoid stromal cells, as displayed in an in vitro model of human lymphoid stromal differentiation and in an inducible mouse model of ectopic lymphoid organ formation [56]. Furthermore, CXCL12 induced primary FL B-cell migration, adhesion to stroma cells, and activation demonstrated phosphorylation of the spleen tyrosine kinase (Syk), another key mediator of B-cell antigen receptor signaling, and its downstream target extracellular signal-regulated kinase (ERK) [56]. FL B-cell migration was similarly reduced in response to a CXCL12 
receptor CXCR4 (Figure 1) inhibitor, the Bruton's tyrosine kinase (BTK) inhibitor ibrutinib, and idelalisib [56].

In mice, Luthje et al. showed that Tfh cells were not terminally differentiated and retained the flexibility to be mobilized into other helper $\mathrm{T}$ cell subsets [64]. They showed that Tfh cells are multifunctional helper T cells that produce interferon (IFN)- $\gamma$, IL-2, and IL-4. These cells proliferate and produce transferrable memory cells with plasticity, which in turn differentiate into conventional effector helper $\mathrm{T}$ and Tfh cells after recall following viral infection [64]. Furthermore, Ame-Thomas et al. identified that the $\mathrm{CD} 10^{+}$subset of Tfh cells from the FL LNs have an IFN- $\gamma^{\text {low }}$ TNF- $\alpha^{\text {high }}$ cytokine profile, which favorably induces and maintains a B-cell supportive lymphoid stromal network linked to a strong capability of support autologous neoplastic B-cell survival in vitro [65]. CD10 is a marker of immature T and B cells. Although Tfh cells obtained from FL secrete high levels of IL-21 and low levels of IL-17 compared with Tfh cells from the tonsils. The CD10+ subset of Tfh cells produces high levels of IL-4 that can cause B-cell activation, survival, and production of CCL17 and CCL22, which recruit Treg (Figure 1) [65]. IL-4 also contributes to TAM polarization (Figure 1) [8]. Thus, creating a vicious cycle, Tfh cells seem to play a role in constructing an immunosuppressive FL microenvironment that accelerates immune escape and FL growth and survival. Blaker et al. showed that high intrafollicular CD4 ${ }^{+} \mathrm{T}$ cell scores at diagnosis were associated with shorter TTT [37].

Interestingly, T-cell receptor repertoire analysis in a Tfh cell subset revealed that the clonality of T cells in follicular areas was greater than that in the interfollicular area in FL $\mathrm{LN}$, with the more frequent clones predominating in the follicular regions as compared with the interfollicular areas [63].

Recently, single-cell transcriptomic data demonstrated that cathepsin S (CTSS) is significantly overexpressed in FL cells as compared to centroblasts and centrocytes from normal GC [66]. Approximately $40 \%$ of FL patients exhibited intermediate-to-high levels of CTSS protein in $10-80 \%$ of FL cells. CTSS can be activated by recurrent Y132D mutations and overexpressed in FL, suggesting a specific and selective role of CTSS in FL lymphomagenesis. In the vavP-Bcl2 chimeric model, histopathological analyses of CTSShigh and CTSS ${ }^{\text {Y132D }}$ tumors showed characteristic features of FL and a significant increase in $\mathrm{CD} 4^{+} \mathrm{Tfh}$ cells. In the animals that overexpressed CTSS or the mutant CTSS, CD8 ${ }^{+} \mathrm{T}$ cells were prone to be eliminated and $\mathrm{CD} 4^{+} \mathrm{T}$ cells were highly infiltrated and colocalized with tumor $\mathrm{B}$ cells. The oncogenic activity of CTSS depends on its capability to accelerate crosstalk between FL cells and Tfh cells; thus, depletion of $\mathrm{CD}^{+} \mathrm{T}$ cells by an anti-CD4 antibody abolishes the ability of vavP-Bcl2-CTSS ${ }^{\text {high }}$ and CTSS ${ }^{Y 132 D}$ to develop tumors due to impaired GC B cell differentiation [66].

Chimeric antigen receptor (CAR)-T cells have demonstrated to be effective against $R / R$ FL [67,68], tFL [69,70], and diffuse large B-cell lymphoma [68-70]. To further target Tfh cells and B-cell lymphoma cells, CAR-T cells targeting CXCR5 have been recently designed with demonstrated comparable activity with conventional CD19 CAR-T cells [71]. However, $\mathrm{CXCR}^{+} \mathrm{CD}^{+} \mathrm{T}$ cells are present in human tonsils and $\mathrm{FL}$ and exhibited strong cytotoxic activity, although the mean fluorescent intensity of CXCR5 in CD8 ${ }^{+} \mathrm{T}$ cells was much lower than B cells and $\mathrm{CD} 4^{+} \mathrm{T}$ cells in human tonsils and FL specimens [72]. Therefore, there is a possibility that the CXCR5 CAR-T might cause fractricide of efficient cytotoxic $\mathrm{T}$ cells. This may explain CXCR5 CAR show similar antitumor activity to CD19 CAR, although they used mantle cell lymphoma cells not FL cells implanted in NOD/Scid/IL2R $\gamma$ null mice [71].

On the contrary, since PI3K is essential for the generation and function of Tfh from the results that $\mathrm{p} 110 \delta$ subunit is pivotal for ICOS downstream signaling and the production of key Tfh cytokines; namely, IL-4 and IL-21 [73]. Therefore, idelalisib can be one of the potent molecular target drugs for CD19 CAR-T cells efficiently to operate, dampening the protumoral components in the FL microenvironment. 
Table 1. Cell components in the microenvironment of follicular lymphoma.

\begin{tabular}{|c|c|c|c|c|}
\hline Cells & Phenotype & $\begin{array}{l}\text { Cytokines/Chemo- } \\
\text { kine } \\
\text { Production }\end{array}$ & Functions in FL & Reference \\
\hline $\begin{array}{l}\text { FRC } \\
\text { (mice) }\end{array}$ & $\begin{array}{l}\mathrm{PDPN} / \mathrm{gp} 38^{+} \\
\mathrm{CD}^{-} 1^{-}\end{array}$ & $\begin{array}{l}\text { IL-8 } \\
\text { CXCL12,13 } \\
\text { CCL2,7,19,21a } \\
\text { (BAFF) }\end{array}$ & FL cell survival & [9] \\
\hline FRC-like cells & - & $\begin{array}{l}\text { IL-6,15, 33 } \\
\text { CCL2, 5,11 } \\
\text { CXCL10 } \\
\text { (ICAM-1个) }\end{array}$ & $\begin{array}{l}\text { Tfh generation } \\
\text { IL-4 production by Tfh } \\
\left(\text { CXCR5 } 5^{+} \text {PD- } 1^{\text {dim }} \text { CD } 4^{+}\right)\end{array}$ & {$[24]$} \\
\hline$(\mathrm{cDCs})$ & $\mathrm{CD}_{11 \mathrm{c}^{+} \mathrm{DCs}}$ & - & Assistance of Treg infiltration & [35] \\
\hline \multirow[t]{5}{*}{ FDCs } & $\mathrm{CCL} 21^{+} \mathrm{CD} 23^{+} \downarrow$ & - & Diffuse growth pattern of FL & [36] \\
\hline & $\mathrm{CD} 21^{+}$ & - & Shorten TTT, PFS, OS & {$[37]$} \\
\hline & $\mathrm{TGII}^{+} \mathrm{FRC} / \mathrm{CD} 5^{+}$ & $\left(\mathrm{CMEs}^{\mathrm{lo}}\right)$ & Reduction in FRCs/FDCs & [38] \\
\hline & $\mathrm{CD} 23^{+} \mathrm{CD} 23^{+} \mathrm{ER} \alpha^{+}$ & - & $\begin{array}{l}\text { Support of G1-2 FL } \\
\text { microenvironment }\end{array}$ & [39] \\
\hline & $\mathrm{CD} 23^{+} \downarrow$ & - & $\begin{array}{l}\text { More haphazard distribution of } \\
\text { S-phase FL cells (i.e., G3 FL) }\end{array}$ & {$[40]$} \\
\hline (HK cells) & $\begin{array}{l}\text { (FDC-like cell derived from } \\
\text { the human tonsil) }\end{array}$ & - & FL cell survival and proliferation & [51] \\
\hline (HK cells) & - & CXCL12 & Cancer stem cell-like activities & [49] \\
\hline (HK cells) & - & $\begin{array}{l}\text { IL-6, 8, } \\
\text { CXCL1, 2, 5,12, } \\
\text { CCL2 }\end{array}$ & $\begin{array}{l}\text { Angiogenesis, FL cell adhesion, } \\
\text { migration, survival, and } \\
\text { proliferation }\end{array}$ & [52] \\
\hline \multirow[t]{5}{*}{ Tfh } & $\begin{array}{l}\mathrm{CD}^{+}{ }^{+} \mathrm{CXCR} 5^{\text {hi }} \mathrm{CCR}^{\mathrm{lo}} \\
\mathrm{ICOS}^{+} \mathrm{PD}-1^{+} \mathrm{BCL}^{+}\end{array}$ & $\begin{array}{l}\text { IL-2, } 10 \\
\mathrm{IFN} \gamma\end{array}$ & - & [59] \\
\hline & $\begin{array}{l}\mathrm{CD}^{+} 4^{+} \mathrm{CXCR}^{\mathrm{hi}} \\
\text { ICOS }^{\text {hi PD- }}{ }^{\text {hi }} \text { CD } 200^{\text {hi }} \\
\text { CD127/IL7-R } \alpha^{\text {lo }}\end{array}$ & $\begin{array}{l}\text { TNF- } \alpha \\
\text { IFN } \gamma \\
\text { IL-4 } \\
\text { (CD40L expression) }\end{array}$ & $\begin{array}{l}\text { FL cell viability support } \\
\text { FL cell viability support } \\
\text { FL cell viability support } \\
\text { and rescue from apoptosis }\end{array}$ & {$[60]$} \\
\hline & $\begin{array}{l}\text { CD } 4^{+} \text {PD-1 } \\
\text { CXCRi } 5^{\text {hi }} \text { BCL } 6^{\text {hi }}\end{array}$ & $\begin{array}{l}\text { IL-4 } \\
\text { IL-4 } \\
\text { (CD40L expression) }\end{array}$ & $\begin{array}{l}\text { pSTAT6 } \uparrow \\
\text { Treg-recruiting CCL17 and CCL22 } \\
\text { production by FL cells }\end{array}$ & {$[61]$} \\
\hline & $\begin{array}{l}\text { CD } 4^{+} \mathrm{CXCR}^{\mathrm{hi}} \\
\mathrm{PD}-1^{\mathrm{hi}} \mathrm{BCL}^{+}\end{array}$ & $\begin{array}{l}\text { IL-4 } \\
\text { (CD40L expression) }\end{array}$ & $\begin{array}{l}\text { CXCL12 } \uparrow \text { i } \\
\text { FL cell migration, adhesion to SCs, } \\
\text { Syk and ERK phosphorylation }\end{array}$ & [56] \\
\hline & $\mathrm{CD}^{+}{ }^{+} \mathrm{PD}-1^{+} \mathrm{ICOS}^{+}$ & - & $\begin{array}{l}\text { FL cell proliferation } \\
\text { Increase in histological grade } \\
\text { Immune synapse formation with } \\
\mathrm{Ki}-67^{+} \\
\text {FL cells }\end{array}$ & [63] \\
\hline
\end{tabular}


Table 1. Cont.

\begin{tabular}{|c|c|c|c|c|}
\hline Cells & Phenotype & $\begin{array}{l}\text { Cytokines/Chemo- } \\
\text { kine } \\
\text { Production }\end{array}$ & Functions in FL & Reference \\
\hline & $\begin{array}{l}\mathrm{CD} 10^{+} \mathrm{PAX} 5^{-} \\
\mathrm{CD}^{+} \mathrm{CD}^{+} \mathrm{CXCR}^{+} \\
\mathrm{PD}^{+} 1^{+} \mathrm{ICOS}^{+} \\
\mathrm{CXCL}^{+}{ }^{+} \\
\mathrm{HLA}^{-} \mathrm{DR}^{+} \mathrm{Ki}^{-} 67^{-}\end{array}$ & $\begin{array}{l}\text { IL- }{ }^{\text {hi }} \text { IFN } \gamma^{\text {lo }} \\
\text { TNF- } \alpha^{\text {hi }} \\
\text { IL- } 21^{\text {hi }} \text { IL- } 17^{\text {lo }} \\
\text { (either CD } 10^{+} \text {or } \\
\text { CD10 }\end{array}$ & $\begin{array}{l}\text { B-cell activation and survival } \\
\text { B-cell supportive lymphoid } \\
\text { stromal network } \\
\text { Treg-recruiting CCL17 and CCL22 } \\
\text { production by FL cells }\end{array}$ & [65] \\
\hline \multirow[t]{7}{*}{ TFRs } & $\begin{array}{l}\mathrm{CD}^{+}{ }^{+} \mathrm{CD} 25^{+} \\
\text {CXCR5 }^{\text {hi ICOS }}{ }^{\text {hi }} \\
\text { Blimp-1/PRDM1 } 1^{+}\end{array}$ & - & - & {$[60]$} \\
\hline & $\mathrm{CD}^{+}{ }^{+} \mathrm{CD} 25^{+} \mathrm{GITR}^{+}$ & - & $\begin{array}{l}\text { Inhibition of FL LN-infiltrating } \\
\text { T-cell cytokine production }\end{array}$ & [74] \\
\hline & 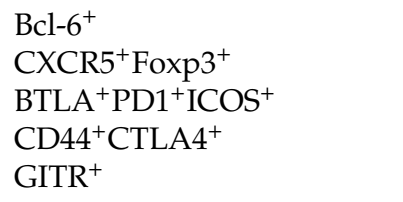 & - & - & [10] \\
\hline & $\begin{array}{l}\mathrm{CD}^{+}{ }^{+} \text {Ooxp }^{+}{ }^{+} \mathrm{Bcl}^{-} 6^{+} \\
\text {Blimp-1/PRDM1 } \\
\text { CXCR5 }{ }^{\text {hi }} \text { PD- } 1{ }^{\text {hi }}\end{array}$ & - & - & [11] \\
\hline & $\begin{array}{l}\text { Foxp }^{+} \mathrm{Ki}^{-} 67^{+} \mathrm{PD}^{-} 1^{+} \\
\mathrm{CXCR}^{+} \mathrm{BCl}-6^{+}\end{array}$ & - & - & [12] \\
\hline & $\begin{array}{l}\mathrm{CD}^{+}{ }^{\mathrm{CD}} 25^{+} \mathrm{GITR}^{+} \\
\text {PD- }{ }^{\mathrm{dim}}{ }^{\mathrm{CXCR}} 5^{+} \text {Foxp }^{+}\end{array}$ & - & - & [75] \\
\hline & $\begin{array}{l}\mathrm{CXCR}^{+} \\
\mathrm{CD}^{+} \\
\mathrm{PD}^{+} 1^{+} \mathrm{CD} 25^{+} \mathrm{BCL6}^{+} \mathrm{FoxP}^{+} \\
\text {CXCL13 } \\
\text { CTLA- }^{+} \mathrm{IL}^{+} 10^{+} \mathrm{GITR}^{+}\end{array}$ & $\begin{array}{l}\text { CCL4 } \\
\text { IL-16 } \\
\text { CXCL13 } \\
\text { (S1PR1 } \downarrow \text { SELL } \downarrow \\
\text { CCR7 } \downarrow)\end{array}$ & $\begin{array}{l}\text { Treg migration to the GC in } \\
\text { response to a CXCL13 (CXCR5 } \\
\text { ligand) gradient } \\
\text { Chemotactic for CCR5-expressing } \\
\text { Tregs } \\
\text { Treg recruitment } \\
\text { Treg retention in the GC } \\
\text { More suppressive than normal LN } \\
\text { Tregs }\end{array}$ & [76] \\
\hline (TFR?) & 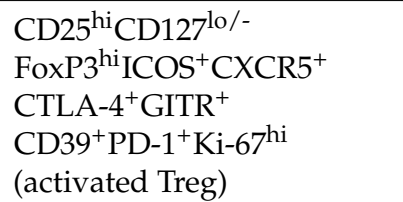 & - & - & [77] \\
\hline
\end{tabular}

FRC, fibroblastic reticular cell; PDPN, podoplanin; gp, glycoprotein; CD, cluster of differentiation; IL, interleukin; CCL, CC chemokine ligand; CXCL, C-X-C motif chemokine; BAFF, B-cell-activating factor belonging to the tumor necrosis factor family; ICAM-1, intercellular adhesion molecule 1 ; $\uparrow$, upregulation; Tfh, T-follicular helper cells; CXCR5, C-X-C chemokine receptor type 5; PD-L1; programmed cell death ligand 1; cDCs, conventional DCs; TG, transglutaminase; ER, estrogen receptor; G, Grade; FDCs, follicular dendritic cells; TTT, time to transformation; PFS, progression-free survival; OS, overall survival; CMEs, collagen modifying enzymes; lo, low; ICOS, inducible $\mathrm{T}$ cell costimulator; PD-1, programmed cell death-1; BCL6, B-cell lymphoma 6; hi, high; pSTAT6, phosphorylated signal transducer and activator of transcription 6; CD40L, CD40 ligand; FL, follicular lymphoma; SCs, stromal cells; Syk, spleen tyrosine kinase; ERK, extracellular signal-regulated kinase; IFN- $\gamma$, interferon gamma; lo, low; CCL, CC chemokine ligand; Tregs, regulatory T cells; TFRs, T-follicular regulatory cells; Blimp-1, B lymphocyte-induced maturation protein-1; PRDM1, positive regulatory domain containing 1, with zinc finger domain; GITR, glucocorticoid-induced tumor necrosis factor-related protein; LN, lymph node; FoxP3, forkhead box protein 3; BTLA, B and T lymphocyte attenuator; CTLA-4' cytotoxic T-lymphocyte-associated protein 4; S1PR1, sphingosine-1-phosphate receptor 1; $\downarrow$, downregulation; SELL, L-selectin; GC, germinal center; Th1,T helper1.

\section{The Herpes Virus Entry Mediator/B- and T-Lymphocyte Attenuator Axis}

Tumor necrosis factor receptor superfamily 14 (TNFRSF14), which encodes the herpes virus entry mediator (HVEM), is the fourth most highly mutated gene in FL [78]. HVEM limits Tcell activation via the ligation of the B- and T-lymphocyte attenuator (BTLA). BTLA contains an immunoreceptor tyrosine-based inhibition motif (ITIM) in its cytoplasmic domain that 
can recruit the Src homology domain 2 (SH2)-containing protein tyrosine phosphatase1 (SHP1) and SHP2 [79]. BTLA-HVEM at the immunological synapse recruits SHP1 to inhibit signaling downstream of the T cell receptor in Tfh cells [80]. HVEM localizes to the minimal common region of the chromosome 1 p36 deletion, which is associated with worse prognosis in FL [81]. In a vavP-BCL2 FL mouse model, in which hematopoietic progenitor cells isolated from fetal livers were transduced with retrovirus expressing short hairpin RNAs to knock-down Hvem, tumors demonstrated significantly increased expression of FDC- and FRC-derived cytokines; namely, CXCL13 and CXCL19, compared with control tumors transfected with vector alone [78]. Since the stroma-derived cytokine CXCL13 is the main chemoattractant for $\mathrm{CXCR} 5^{+}$Tfh cells (Figure 1) [82], a significant increase in the proportion of Tfh cells secreting a high quantity of IL-4, TNF- $\alpha$, and LT (Figure 1) in HVEM-deficient tumors was observed compared with control tumors [78]. Moreover, immunohistofluorescence staining demonstrated a significant increase in the $\mathrm{CD} 21^{+} \mathrm{CD} 35^{+}$ FDC network (Figure 1) within follicles in HVEM-deficient tumors compared with control tumors. Similarly, as a result of the activation of FRCs, the intensity of type I collagen in perifollicular regions was significantly elevated in HVEM-deficient lymphomas [78]. Human GC-derived Tfh cells are characterized by high expression of the BTLA receptor [78]. The Tfh-derived cytokine IL-4 phosphorylates STAT6 and significantly increased STAT6 phosphorylation was found in HVEM-low human FLs [78]. Thus, in HVEM-deficient FLs, Tfh cell recruitment and B cell activation were observed.

In particular, HVEM/TNFRSF14 loss was found in $30-40 \%$ of FL patients $[78,83]$. In addition, $\mathrm{HVEM}^{-}$FL patients exhibited greater expansion of Tfh cells than $\mathrm{HVEM}^{+}$ FL patients. Using mouse B-cell lymphoma cells, a soluble HVEM ectodomain protein fragment blocked BTK phosphorylation, similar to ibrutinib. Furthermore, soluble HVEM inhibited the B-cell receptor signals via Syk and the B cell linker, and ERK phosphorylation in primary human FL B cells and in DoHH2 human lymphoma cells derived from tFL that expressed BTLA and carried a homozygous HVEM deletion. Moreover, since it prevents the growth of aggressive $\mathrm{Myc}^{+} \mathrm{Bcl}^{+}$murine lymphoma cells that express BTLA and lack HVEM in vivo, CAR-T cells that restore loss of HVEM are a promising therapeutic strategy [78].

In contrast, mutations or deletions in BTLA were not found [78]. Since BTLA expression is controlled by the histone lysin N-methyltransferase 2D (KMT2D), it is plausible that reduced BTLA expression in FL may be attributed to KMT2D inactivation [78], as truncating and missense mutations affecting KMT2D were observed in $60-70 \%$ of FL patients, and loss of KMT2D results in decreased global lysine 4 on histone $\mathrm{H} 3$ methylation levels and downregulation of key genes involved in immune signaling and B cell differentiation [84]. However, BTLA expression in the intrafollicular area was found to be a marker of Tfh cells, whereas its expression in the interfollicular area was a marker of T cells in FL, with high BTLA expression being correlated with a favorable overall survival in FL [85]. In addition, tFL was characterized by a remarkable decrease in the number of BTLA ${ }^{+}$cells. Furthermore, high TNFRSF14 expression was found to be correlated with poor OS and PFS. In addition, TNFRSF14 ${ }^{\text {high }}$ correlated with B-symptoms, high $\beta 2$-microglobulin, and high-risk groups according to the FL international prognostic index [85]. Since the interaction between the HVEM and BTLA receptors is ablated in the majority of FLs, modified CD19-targeted CAR-T cells that enable locally compensate the soluble HVEM were significantly more effective than conventional CD19-targeted CAR-T cells against lymphoma cells [78].

Recently, interesting findings have been reported concerning epcoritamab, a novel bispecific IgG1 antibody redirecting $\mathrm{CD}^{+} \mathrm{T}$ cells to $\mathrm{CD}^{2} \mathrm{O}^{+}$-expressing tumor cells. An ongoing first-in-human clinical trial on epcoritamab showed a favorable safety profile and preliminary efficacy data indicating encouraging antitumor activity as a single agent in patients with R/R B-NHLs, including FL [86]. Noteworthy, van der Horst et al. [87] found no association between T-cell activation and tumor expression of CD20, PD-L1, or HLA-DR. Activation of allogenic $\mathrm{CD}^{+}$and $\mathrm{CD}^{+} \mathrm{T}$ cells was the highest in patients that showed low expression of HVEM in B-NHL cells, including FL. T-cell activation was significantly 
lower in patients with higher tumor HVEM expression. However, no relationship was observed between HVEM expression and epcoritamab-dependent cytotoxicity [87]. This corroborates the previous findings that frequencies of polyfunctional alloreactive T-cell, which was defined combining intracellular measurements of IFN- $\gamma$, IL-2, or TNF- $\alpha$ and surface expression of CD107a, after stimulation with FL B cells harboring dual aberrations (for example, homozygous deletions, nonsense mutations and deletions) were higher than FL B cells with wild-type TNFRSF14 [83]. This implies that HVEM- FL B-cells seem to be immunogenic.

\section{T-follicular Regulatory Cells}

Tregs expressing T-bet can upregulate CXCR3, urging them to traffic to sites of Th1 inflammation and thus suppress Th1 cells. FL-infiltrating Tregs have been demonstrated to potentially inhibit proliferation and the cytokine production of FL-infiltrating T cells [74]. Tregs that localize in the GC are a distinct subset of Tregs called TFRs [10-12]. T-cell population is characterized by the dual expression of FoxP3 and BCL6 (Table 1) [10-12,60,75]. In mice, TFRs originate from naïve Tregs that upregulate BCL6 upon activation, leading to CXCR5 expression that direct TFRs to the GC through gradients of CXCL13 [10-12]. In contrast, human FL TFRs in part originate from Tfh cells [13], supporting FL B-cell viability [60]. MSCs promote the differentiation of Tfh cells into TFR by inducing the expression of FoxP3 [13]. MSCs support the viability of FL-infiltrating Tfh cells in part through an IL-6-dependent mechanism [13]. TFRs express a cytokine/chemokine profile that is unique compared with Tregs in normal LN. Cell migration and movement categories were highly enriched in FL LNs compared with normal LNs. Significant differences were found in cytokine, chemokine, G-protein receptor, and adhesion molecule genes. Moreover, RNA sequencing data revealed that TFR has greater suppressive capacity than Tregs in normal LN or reactive LN by upregulating cytotoxic T-lymphocyte-associated protein 4 (CTLA-4), IL-10, and glucocorticoid-induced tumor necrosis factor-related protein (GITR), all of which were confirmed by protein expression [76]. IL-16 is also abundantly secreted by TFRs compared with normal LN, although IL-16 preferentially attracts Th1 and Treg subsets. In addition, they showed that TFRs produce more C-C motif chemokine ligand 3 (CCL3) (also known as macrophage inflammatory protein-1 (MIP-1) $\alpha$ ) and 4 (CCL4) (also known as MIP-1 $\beta$ )), chemoattractants for CCR5-expressing Tregs, and CD4 ${ }^{+}$and $\mathrm{CD}^{+} \mathrm{T}$ cells, than Tregs in normal LNs. Furthermore, TFRs express CXCL13, which suggests that there is an autocrine feedback that resulted in TFR retention in the GC. TFRs localize and accumulate within malignant LNs through the downregulation of SELL (encoding L-selectin), CCR7, and sphingosine-1-phosphate receptor 1, a type 1 G-protein coupled receptor that is a primary determinant of lymphocyte egress from the LN. The SELL expression in TFRs was lower than that in normal LNs, suggesting TFR retention in the GC [76].

Tregs usually express the IL-2 receptor $\alpha$ chain CD25, but lack the IL-7 receptor $\alpha$ chain CD127. Le et al. showed that CD25 $5^{\text {high }} \mathrm{CD} 127^{\text {low } /-}$ Tregs were accumulated in FL samples, and that the proportion of $\mathrm{ICOS}^{+}$Tregs among $\mathrm{CD}^{+} \mathrm{T}$ cells was significantly increased in FL tumors [77]. Compared with ICOS ${ }^{-}$Tregs, FL tissues showed significant augmentation of surface CTLA-4, GITR, CD39, PD-1, and higher Ki67, which suggested that activated Tregs expanded in the FL microenvironment [77]. A decrease in ICOS ligand (ICOSL) expression in FL B cells was observed in the presence of $\mathrm{ICOS}^{+} \mathrm{CD}^{+} \mathrm{T}$ cells in vitro, and antagonist anti-ICOS antibody restored the high expression of ICOSL in FL B cells, suggesting that the ICOS/ICOSL interplay is involved in the downregulation of ICOS expression in FL B cells [77]. ICOS expression was markedly higher in CD25 $5^{\text {high }}$ FoxP $3{ }^{\text {high }}$ Tregs, which were shown to produce less IL- 2 and IFN $-\gamma$ than $\mathrm{CD} 25^{+} \mathrm{Foxp}^{+}$Tregs. Therefore, when a neutralizing anti-ICOS or anti-ICOSL monoclonal antibody was added to cocultures of $\mathrm{CD}^{+} \mathrm{T}$ cells and FL B cells, a significant reduction in the percentage of CD25 $5^{\text {high }} \mathrm{FoxP} 3{ }^{\text {high }}$ Tregs was observed [77]. Since about $25 \%$ of conventional T cells in mononuclear cell extracts from FL samples are Tfh cells characterized by ICOS and CXCR5 expression [77], 
the ICOS/ICOSL pathway between FL-supporting Tfh and FL B cells can be sensitive to treatment with anti-ICOS/ICOSL antibody as well.

One of the potential approaches to deplete Tregs is the anti-CTLA-4 antibody. The results of a phase I study on ipilimumab combined with rituximab in R/R B-NHL patients, where FL was enrolled as the highest population (39\%), showed manageable toxicities and encouraging efficacy. In this trial, the ratio of CD45RA ${ }^{-}$Tregs to total Tregs was significantly increased in responders compared to non-responders over the examined period of time (days 0, 8, 15, and 70) [88], although Tregs in peripheral blood do not reflect Tregs in LN, especially TFRs.

Furthermore, epigenetic regulator zeste hololog 2 (EZH2) is a catalytic subunit of polycomb repressive complex 2 that trimethylates lysine 27 on histone $\mathrm{H3}$ [89], resulting in gene repression, and EZH2 can form a complex with FoxP3 that is fundamental to maintaining the identity of naturally occurring Tregs following its activation [90]. The modulation of the EZH2 expression in T cells can improve antitumor responses elicited especially in the presence of the anti-CTLA-4 therapy. Blockade of CTLA-4 signaling enhanced $E Z H 2$ expression in human $\mathrm{CD}^{+}$effector T cells and $\mathrm{CD} 8^{+} \mathrm{T}$ cells and Tregs, whereas EZH2 inhibition improves response to anti-CTLA-4 via modulation of cytotoxic effector T cells and altering the Treg phenotype into effector-like T cell profile [91]. Recently, tazemetostat, a first-in-class, selective, oral EZH2 inhibitor, which inhibits either wild type or mutant, showed clinically durable responses in heavily pretreated patients with R/R FL [92], although activating mutations of EZH2 are present in $20-30 \%$ of patients with FL and tFL $[93,94]$. Intriguingly, EZH2 expression is elevated in tumor-infiltrating Tregs, and pharmacological inhibition of EZH2 destabilize FOXP3 expression and slows tumor growth through enhancement of the recruitment and function of $\mathrm{CD} 8^{+}$and $\mathrm{CD} 4^{+}$ $\mathrm{T}$ cells [95]. Thus, tazemetostat target FL B-cells with recurrent EZH2 gain-of-function mutations and modulate FOXP3 expression in TFRs. Furthermore, idelalisib was recently shown preferentially to inhibit human Tregs compared with $\mathrm{CD} 4^{+}$and $\mathrm{CD} 8^{+}$effector $\mathrm{T}$ cells [96]. Collectively, these kinds of the functional TFR modulators combined with anti-B-cell drugs should be explored.

\section{Other T Cell Dysfunctions in FL}

The immunomodulatory drug lenalidomide (Revlimid) combined with rituximab $\left(R^{2}\right.$ immunotherapy) was recently approved for relapsed or refractory indolent B-cell lymphoma, including FL [97]. By the combination of lenalidomide with rituximab, restoration of appropriate F-actin immune synapse formation was confirmed by confocal images of clinical samples obtained from LN biopsies conjugated with circulating tumor B cells obtained from patients with leukemic state of $\mathrm{FL}$, accompanied with polarized expression of granzyme $\mathrm{B}$ at $\mathrm{CD} 8^{+} \mathrm{T}$ cell contact sites and synapses with FL B cell and with tyrosine phosphorylated proteins in $\mathrm{CD}^{+} \mathrm{T}$ cells [98].

Recently, T-cell immunoglobulin and ITIM domain (TIGIT) has been highlighted as a coinhibitory receptor in FL. The majority of $\mathrm{CD}^{+}$effector memory $\mathrm{T}$ cells from lymphoma coexpress TIGIT and PD-1 as compared to tonsillar cells (Figure 1) [99]. Among CD8 ${ }^{+}$ T cells, intracellular TNF- $\alpha$ and IL- 2 were significantly diminished in PD- ${ }^{+}$TIGIT $^{+}$and PD- $1^{+}$TIGIT $^{-}$cells as compared to PD- ${ }^{-}$TIGIT $^{-}$cells, and the same trend was found for IFN- $\gamma$, indicating that TIGIT and PD- 1 contribute to suppress the T-cell effector function. TIGIT is expressed by the majority of Th cells from the FL LN and by Tfh cells in tonsils from healthy donors (Figure 1) [99]. The TIGIT ligand either CD112 or CD155 was not expressed by tumor cells in all examined FL patients [99], but were expressed by FDCs in the FL microenvironment (Figure 1) [100]. TIGIT competes for ligand binding with the costimulatory receptor $\mathrm{CD} 226$. $\mathrm{CD}^{+}$effector memory $\mathrm{T}$ cells showed the highest expression of TIGIT but low expression of CD226. Contrary to CD8 ${ }^{+} \mathrm{T}$ cells, CD226 was often expressed in $\mathrm{TIGIT}^{+} \mathrm{CD} 4^{+} \mathrm{T}$ cells, including Tfh cells (Figure 1). This indicates that lower expression of CD226 on CD8 ${ }^{+} \mathrm{T}$ cells might play a role in TIGIT-mediated inhibition of $\mathrm{CD}^{+} \mathrm{T}$ cells in FL [99]. Upon ligation, TIGIT mobilizes the SH2-containing inositol 
5-phosphatase 1 to alleviate the signals downstream of the adaptor protein SH2-domain containing leukocyte protein of $76 \mathrm{kDa}$, which results in ERK dephosphorylation and subsequent inhibition of IFN- $\gamma$ production. Thus, TIGIT plays a role in dampening CD8 ${ }^{+}$ T-cell antitumor response in FL. Moreover, Yang et al. showed that the higher levels of TIGIT on $\mathrm{CD}^{+}{ }^{+} \mathrm{T}$ cells were attributed to the abundant expression of Treg and Tfh cells in FL. Furthermore, TIGIT preferentially expresses CD28 ${ }^{-} \mathrm{CD} 57^{+}$or $\mathrm{CD} 27^{-} \mathrm{CD} 57^{+} \mathrm{CD} 8^{+}$ $\mathrm{T}$ cells, which suggests late-stage memory cells, defined as a population that exhibits an exhausted phenotype [101]. Finally, they demonstrated that increased numbers of TIGIT $^{+} \mathrm{T}$ cells related to inferior survival in FL patients [101]. Therefore, the immune checkpoint blockade targeting TIGIT enables a highly powerful T-cell antitumor response in several ways, by restoring the antitumor potential of $\mathrm{T}$ effector cells, dampening the Treg immunosuppressive effect, and diminishing the tumor-supporting effects of Tfh cells in FL.

Additionally, the lymphocyte-activation gene 3 (LAG-3) was found to be expressed on a subset of intratumoral $\mathrm{T}$ cells in $\mathrm{FL}$, most of which were almost exclusively originated from the $\mathrm{PD}-1^{+}$population (Figure 1) [102]. Intratumoral PD- $1^{+} \mathrm{LAG}-3^{+} \mathrm{CD} 4^{+}$or $\mathrm{CD} 8^{+} \mathrm{T}$ cells exhibit reduced capability to secrete IFN- $\gamma$, IL-2, granzyme B, and perforin [89]. Moreover, the numbers of $\mathrm{CD}^{+} \mathrm{LAG}-3^{+}$or $\mathrm{TIM}-3^{+} \mathrm{LAG}-3^{+}$cells were found to be correlated with poorer survival in FL patients [102].

Mass cytometry data further showed that intratumoral $\mathrm{T}$ cells lacking expression of CD27 and CD28 costimulatory receptor are enriched in FL and related to inferior OS in FL patients [103]. Moreover, CD70 is abundantly expressed in FL cells when compared to tonsil, and $\mathrm{CD} 70^{+}$lymphoma cells contribute to the expansion of $\mathrm{CD} 27^{-} \mathrm{CD} 28^{-} \mathrm{T}$ cells This analysis demonstrated that both CD27 and CD28 are diminished in T cells cocultured with human lymphoma cells, which was reversed with an anti-CD70 antibody [103].

Recently, Pangault et al. proposed a tolerogenic niche for FL [104]. They compared the expression of CD200 between MSCs, B cells, and Tfh cells between FL and tonsils, which revealed that CD200 was significantly overexpressed in B cells and Tfh cells in FL LNs. In turn, CD200R was expressed on classical DC from FL LNs [104]. Therefore, CD200-CD200R engagement may confer an immunoregulatory signal, which results in the suppression of a T-cell-mediated immune response.

\section{Conclusions}

Considering the main players abovementioned $\mathrm{CD} 4^{+} \mathrm{T}$-cell subpopulations supporting FL cells in the tumor microenvironment, Tfh and TFR cells could represent a therapeutic approach for the management of FL. Given the potential of the PI3K p1108 isoform inhibitor idelalisib simultaneously to inhibit proneoplastic cells in the FL microenvironment and to reduce the neoplastic $B$ cells, Tfh cells and TFRs could reinforce the effects of the cytotoxic T cells. Hopefully, targeting EZH2 reprograms intratumoral Tregs; as for FL, namely, TFRs, which are more suppressive than Tregs in normal LNs, adoptive transfer of CAR-T cell therapy can be efficaciously executed even in the immunosuppressive tumor microenvironment. This combinatory strategy should be explored as a treatment options to tackle FL as armament in a straightforward direction instead of invigorating dysfunctional cytotoxic $\mathrm{T}$ cell therapies; otherwise, relapse will continue to persist among these FL patients.

Funding: This research receives no external funding.

Institutional Review Board Statement: Not applicable.

Informed Consent Statement: Not applicable.

Data Availability Statement: Not applicable.

Conflicts of Interest: The authors declare no conflict of interest. 


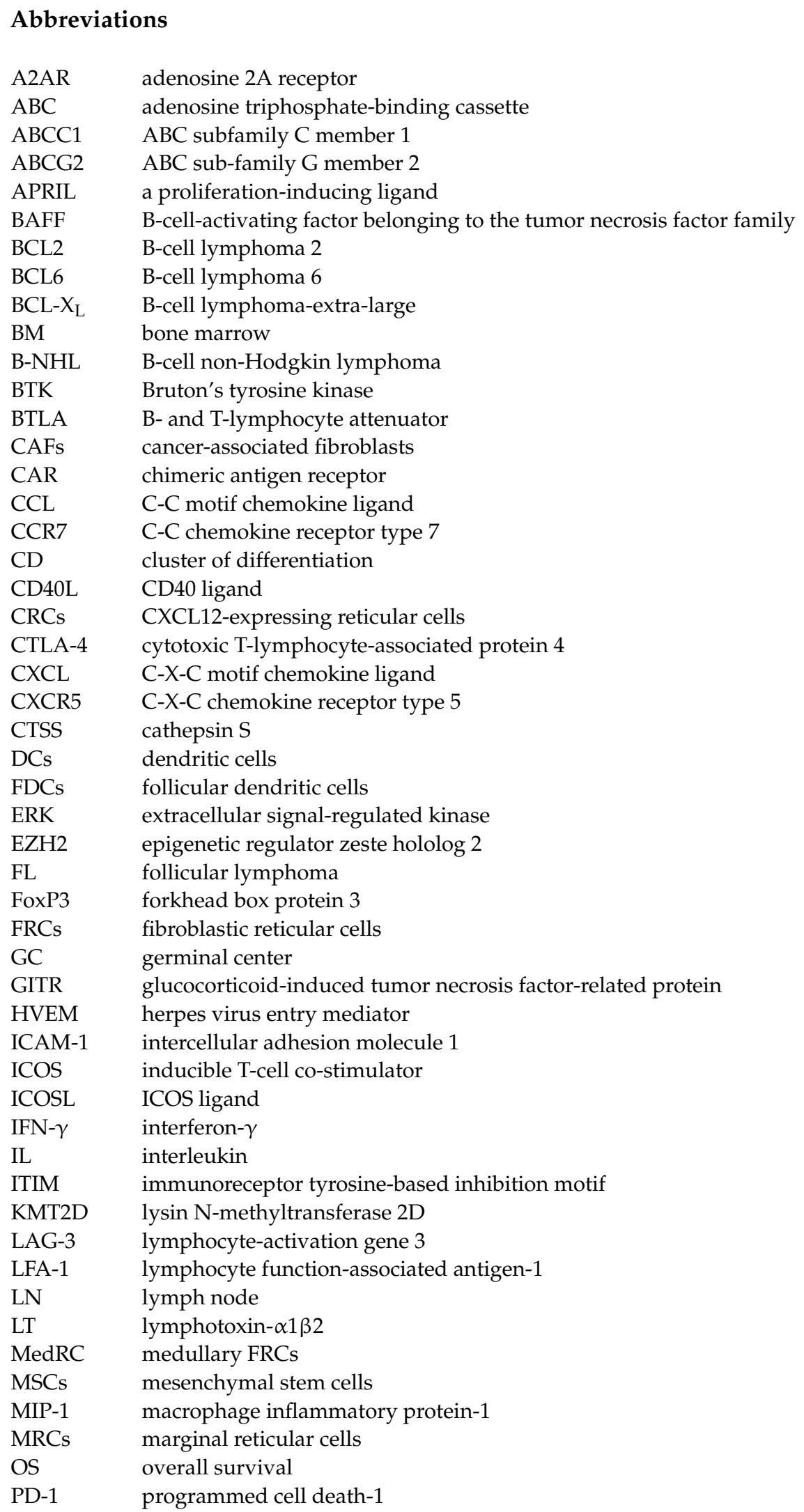




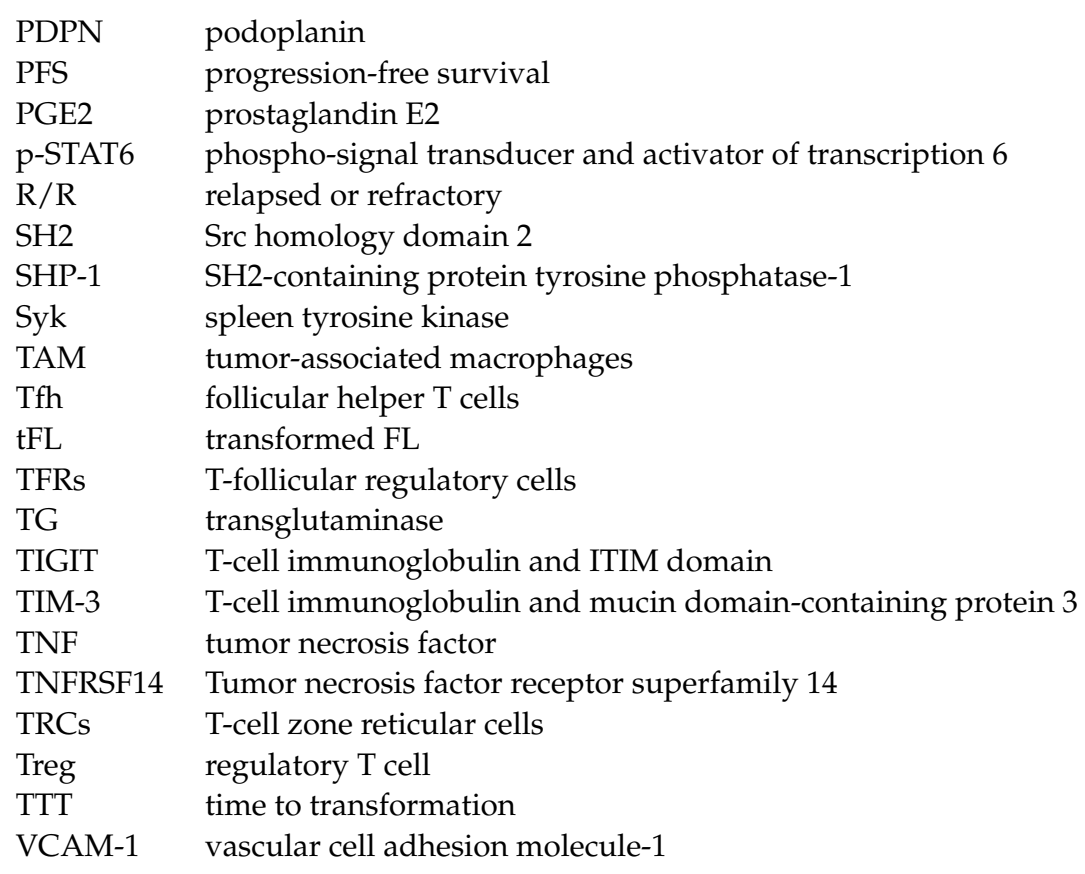

\section{References}

1. Montoto, S.; Davies, A.J.; Matthews, J.; Calaminici, M.; Norton, A.J.; Amess, J.; Vinnicombe, S.; Waters, R.; Rohatiner, A.Z.; Lister, T.A. Risk and clinical implications of transformation of follicular lymphoma to diffuse large B-cell lymphoma. J. Clin. Oncol. 2007, 25, 2426-2433. [CrossRef] [PubMed]

2. Al-Tourah, A.J.; Gill, K.K.; Chhanabhai, M.; Hoskins, P.J.; Klasa, R.J.; Savage, K.J.; Sehn, L.H.; Shenkier, T.N.; Gascoyne, R.D.; Connors, J.M. Population-based analysis of incidence and outcome of transformed non-Hodgkin's lymphoma. J. Clin. Oncol. 2008, 26, 5165-5169. [CrossRef]

3. Watanabe, T.; Tobinai, K.; Wakabayashi, M.; Morishima, Y.; Kobayashi, H.; Kinoshita, T.; Suzuki, T.; Yamaguchi, M.; Ando, K.; Ogura, M.; et al. Outcomes after R-CHOP in patients with newly diagnosed advanced follicular lymphoma: A 10-year follow-up analysis of the JCOG0203 trial. Lancet Haematol. 2018, 5, e520-e531. [CrossRef]

4. Kridel, R.; Xerri, L.; Gelas-Dore, B.; Tan, K.; Feugier, P.; Vawda, A.; Canioni, D.; Farinha, P.; Boussetta, S.; Moccia, A.A.; et al. The prognostic impact of CD163-positive macrophages in follicular lymphoma: A study from the BC cancer agency and the lymphoma study association. Clin. Cancer Res. 2015, 21, 3428-3435. [CrossRef]

5. Farinha, P.; Al-Tourah, A.; Gill, K.; Klasa, R.; Connors, J.M.; Gascoyne, R.D. The architectural pattern of FOXP3-positive T cells in follicular lymphoma is an independent predictor of survival and histologic transformation. Blood 2010, 115, 289-295. [CrossRef]

6. Carreras, J.; Lopez-Guillermo, A.; Fox, B.C.; Colomo, L.; Martinez, A.; Roncador, G.; Montserrat, E.; Campo, E.; Banham, A.H. High numbers of tumor-infiltrating FOXP3-positive regulatory $\mathrm{T}$ cells are associated with improved overall survival in follicular lymphoma. Blood 2006, 108, 2957-2964. [CrossRef] [PubMed]

7. Yang, Z.-Z.; Grote, D.M.; Ziesmer, S.C.; Xiu, B.; Novak, A.J.; Ansell, S.M. PD-1 expression defines two distinct T-cell subpopulations in follicular lymphoma that differentially impact patient survival. Blood Cancer J. 2015, 5. [CrossRef]

8. Wang, H.W.; Joyce, J.A. Alternative activation of tumor-associated macrophages by IL-4 Priming for protumoral functions. Cell Cycle 2010, 9, 4824-4835. [CrossRef] [PubMed]

9. Malhotra, D.; Fletcher, A.L.; Astarita, J.; Lukacs-Kornek, V.; Tayalia, P.; Gonzalez, S.F.; Elpek, K.G.; Chang, S.K.; Knoblich, K.; Helmer, M.E.; et al. Transcriptional profiling of stroma from inflamed and resting lymph nodes defines immunological hallmarks. Nat. Immunol. 2012, 13, 499-510. [CrossRef] [PubMed]

10. Chung, Y.; Tanaka, S.; Chu, F.; I Nurieva, R.; Martinez, G.J.; Rawal, S.; Wang, Y.-H.; Lim, H.; Reynolds, J.M.; Zhou, X.-H.; et al. Follicular regulatory T cells expressing Foxp3 and Bcl-6 suppress germinal center reactions. Nat. Med. 2011, 17, 983-988. [CrossRef]

11. Linterman, M.A.; Pierson, W.; Lee, S.K.; Kallies, A.; Kawamoto, S.; Rayner, T.F.; Srivastava, M.; Divekar, D.P.; Beaton, L.; Hogan, J.J.; et al. Foxp3+ follicular regulatory T cells control the germinal center response. Nat. Med. 2011, 17, 975-982. [CrossRef]

12. Wollenberg, I.; Agua-Doce, A.; Hernández, A.; Almeida, C.; Oliveira, V.G.; Faro, J.; Graca, L. Regulation of the germinal center reaction by Foxp3+ follicular regulatory T cells. J. Immunol. 2011, 187, 4553-4560. [CrossRef]

13. Brady, M.T.; Hilchey, S.P.; Hyrien, O.; Spence, S.A.; Bernstein, S.H. Mesenchymal stromal cells support the viability and differentiation of follicular lymphoma-infiltrating follicular helper T-cells. PLoS ONE 2014, 9, e97597. [CrossRef] [PubMed]

14. Link, A.; Vogt, T.K.; Favre, S.; Britschgi, M.R.; Acha-Orbea, H.; Hinz, B.; Cyster, J.G.; Luther, S.A. Fibroblastic reticular cells in lymph nodes regulate the homeostasis of naive T cells. Nat. Immunol. 2007, 8, 1255-1265. [CrossRef] [PubMed] 
15. Zhang, Y.; Tech, L.; George, L.A.; Acs, A.; Durrett, R.E.; Hess, H.; Walker, L.S.K.; Tarlinton, D.M.; Fletcher, A.L.; Hauser, A.E.; et al. Plasma cell output from germinal centers is regulated by signals from Tfh and stromal cells. J. Exp. Med. 2018, 215, 1227-1243. [CrossRef] [PubMed]

16. Astarita, J.L.; Cremasco, V.; Fu, J.; Darnell, M.C.; Peck, J.R.; Nieves-Bonilla, J.M.; Song, K.; Kondo, Y.; Woodruff, M.C.; Gogineni, A.; et al. The CLEC-2-podoplanin axis controls the contractility of fibroblastic reticular cells and lymph node microarchitecture. Nat. Immunol. 2015, 16, 75-84. [CrossRef] 
17. Brown, F.D.; Turley, S.J. Fibroblastic reticular cells: Organization and regulation of the T lymphocyte life cycle. J. Immunol. 2015, 194, 1389-1394. [CrossRef] [PubMed]

18. Lukacs-Kornek, V.; Malhotra, D.; Fletcher, A.L.; E Acton, S.; Elpek, K.G.; Tayalia, P.; Collier, A.R.; Turley, S.J. Regulated release of nitric oxide by nonhematopoietic stroma controls expansion of the activated T cell pool in lymph nodes. Nat. Immunol. 2011, 12, 1096-1104. [CrossRef]

19. Knoblich, K.; Migoni, S.C.; Siew, S.M.; Jinks, E.; Kaul, B.; Jeffery, H.C.; Baker, A.T.; Suliman, M.; Vrzalikova, K.; Mehenna, H.; et al. The human lymph node microenvironment unilaterally regulates T-cell activation and differentiation. PLoS Biol. 2018, 16, e2005046. [CrossRef]

20. Routy, J.-P.; Routy, B.; Graziani, G.M.; Mehraj, V. The kynurenine pathway Is a double-edged sword in immune-privileged sites and in cancer: Implications for immunotherapy. Int. J. Tryptophan Res. 2016, 9, 67-77. [CrossRef]

21. Sreeramkumar, V.; Fresno, M.; Cuesta, N. Prostaglandin E2 and T cells: Friends or foes? Immunol. Cell Biol. 2011, 90, 579-586. [CrossRef]

22. Baratelli, F.; Lin, Y.; Zhu, L.; Yang, S.-C.; Heuzé-Vourc'H, N.; Zeng, G.; Reckamap, K.; Dohadwala, M.; Sharma, S.; Dubinett, S.M. Prostaglandin E2 induces FOXP3 gene expression and T regulatory cell function in human CD4+ T cells. J. Immunol. 2005, 175, 1483-1490. [CrossRef] [PubMed]

23. Kjaergaard, J.; Hatfield, S.; Jones, G.; Ohta, A.; Sitkovsky, M. A2A adenosine receptor gene deletion or synthetic A2A antagonist liberate tumor-reactive CD8(+) T cells from tumor-induced immunosuppression. J. Immunol. 2018, 201, 782-791. [CrossRef]

24. Misiak, J.; Jean, R.; Rodriguez, S.; Deleurme, L.; Lamy, T.; Tarte, K.; Amé-Thomas, P. Human lymphoid stromal cells contribute to polarization of follicular T cells into IL-4 secreting cells. Front. Immunol. 2020, 11. [CrossRef] [PubMed]

25. Meli, A.P.; Fontés, G.; Avery, D.T.; Leddon, S.A.; Tam, M.; Elliot, M.; Ballesteros-Tato, A.; Miller, J.; Stevenson, M.M.; Fowell, D.J.; et al. The Integrin LFA-1 controls T follicular Helper CELL generation and maintenance. Immunity 2016, 45, 831-846. [CrossRef] [PubMed]

26. Mionnet, C.; Mondor, I.; Jorquera, A.; Loosveld, M.; Maurizio, J.; Arcangeli, M.-L.; Ruddle, N.H.; Nowak, J.; Aurrand-Lions, M.; Luche, H.; et al. Identification of a new stromal cell type involved in the regulation of inflamed B cell follicles. PLoS Biol. 2013, 11, e1001672. [CrossRef]

27. Rodda, L.B.; Bannard, O.; Ludewig, B.; Nagasawa, T.; Cyster, J.G. Phenotypic and morphological properties of germinal center dark zone Cxcl12-expressing reticular cells. J. Immunol. 2015, 195, 4781-4791. [CrossRef]

28. Rodda, L.B.; Lu, E.; Bennett, M.L.; Sokol, C.L.; Wang, X.; Luther, S.A.; Barres, B.A.; Luster, A.D.; Ye, C.J.; Cyster, J.G.; et al. Single-cell RNA sequencing of lymph node stromal cells reveals niche-associated heterogeneity. Immunity 2018, 48, 1014-1028. [CrossRef]

29. Huang, H.-Y.; Rivas-Caicedo, A.; Renevey, F.; Cannelle, H.; Peranzoni, E.; Scarpellino, L.; Hardie, D.L.; Pommier, A.; Schaeuble, K.; Favre, S.; et al. Identification of a new subset of lymph node stromal cells involved in regulating plasma cell homeostasis. Proc. Natl. Acad. Sci. USA 2018, 115, E6826-E6835. [CrossRef]

30. Bénézech, C.; Mader, E.; Desanti, G.; Khan, M.; Nakamura, K.; White, A.; Ware, C.F.; Anderson, G.; Caamaňo, J.H. Lymphotoxinbeta receptor signaling through NF-kappaB2-RelB pathway reprograms adipocyte precursors as lymph node stromal cells. Immunity 2012, 37, 721-734. [CrossRef]

31. Sitnik, K.M.; Wendland, K.; Weishaupt, H.; Uronen-Hansson, H.; White, A.J.; Anderson, G.; Kotarsky, K.; Agace, W.W. Contextdependent development of lymphoid stroma from adult CD34(+) adventitial progenitors. Cell Rep. 2016, 14, 2375-2388. [CrossRef] [PubMed]

32. Golub, R.; Tan, J.; Watanabe, T.; Brendolan, A. Origin and immunological functions of spleen stromal cells. Trends Immunol. 2018, 39, 503-514. [CrossRef] [PubMed]

33. Amin, R.; Mourcin, F.; Uhel, F.; Pangault, C.; Ruminy, P.; Dupré, L.; Guirriec, M.; Marchand, T.; Fest, T.; Lamy, T.; et al. DCSIGN-expressing macrophages trigger activation of mannosylated IgM B-cell receptor in follicular lymphoma. Blood 2015, 126, 1911-1920. [CrossRef] [PubMed]

34. Kuppers, R.; Stevenson, F.K. Critical influences on the pathogenesis of follicular lymphoma. Blood 2018, 131, 2297-2306. [CrossRef]

35. Chevalier, N.; Mueller, M.; Mougiakakos, D.; Ihorst, G.; Marks, R.; Schmitt-Graeff, A.; Veelken, H. Analysis of dendritic cell subpopulations in follicular lymphoma with respect to the tumor immune microenvironment. Leuk. Lymphoma 2015, 57, 2150-2160. [CrossRef]

36. Pepe, G.; Di Napoli, A.; Cippitelli, C.; Scarpino, S.; Pilozzi, E.; Ruco, L. Reduced lymphotoxin-beta production by tumour cells is associated with loss of follicular dendritic cell phenotype and diffuse growth in follicular lymphoma. J. Pathol. Clin. Res. 2018, 4, 124-134. [CrossRef] [PubMed]

37. Blaker, Y.N.; Spetalen, S.; Brodtkorb, M.; Lingjaerde, O.C.; Beiske, K.; Østenstad, B.; Sander, B.; Wahlin, B.E.; Melen, C.M.; Myklebust, H.; et al. The tumour microenvironment influences survival and time to transformation in follicular lymphoma in the rituximab era. Br. J. Haematol. 2016, 175, 102-114. [CrossRef]

38. Ohe, R.; Aung, N.Y.; Meng, H.; Kabasawa, T.; Suto, A.; Tamazawa, N.; Yang, S.; Kato, T.; Yamakawa, M. Localization of collagen modifying enzymes on fibroblastic reticular cells and follicular dendritic cells in non-neoplastic and neoplastic lymphoid tissues. Leuk. Lymphoma 2015, 57, 1687-1696. [CrossRef] 
39. Ohe, R.; Meng, H.-X.; Aung, N.Y.; Yamada, A.; Kabasawa, T.; Utsunomiya, A.; Tamazawa, N.; Tamura, Y.; Kitaoka, T.; Hashimoto, T.; et al. Differential expression of estrogen receptor-alpha on follicular dendritic cells from patients with grade 1-2 and grade 3 follicular lymphoma. Hematol. Oncol. 2019, 37, 151-159. [CrossRef] [PubMed]

40. Kurshumliu, F.; Sadiku-Zehri, F.; Qerimi, A.; Vela, Z.; Jashari, F.; Bytyci, S.; Rashiti, V.; Sadiku, S. Divergent immunohistochemical expression of CD21 and CD23 by follicular dendritic cells with increasing grade of follicular lymphoma. World J. Surg. Oncol. 2019, 17. [CrossRef] [PubMed]

41. Ohe, R.; Meng, H.; Yamada, A.; Aung, N.Y.; Kabasawa, T.; Tamura, Y.; Utsunomiya, A.; Tamazawa, N.; Kawamura, I.; Kitaoka, T.; et al. Good prognosis for follicular lymphoma with estrogen receptor alpha-positive follicular dendritic cells. Hematol. Oncol. 2020, 38, 293-300. [CrossRef] [PubMed]

42. Gopal, A.K.; Kahl, B.S.; de Vos, S.; Wagner-Johnston, N.D.; Schuster, S.J.; Jurczak, W.J.; Flinn, I.W.; Flowers, C.R.; Martin, P.; Viardot, A.; et al. PI3Kdelta inhibition by idelalisib in patients with relapsed indolent lymphoma. N. Engl. J. Med. 2014, 370, 1008-1018. [CrossRef]

43. Serrat, N.; Guerrero-Hernandez, M.; Matas-Cespedes, A.; Yahiaoui, A.; Valero, J.G.; Nadeu, F.; Clot, G.; Di Re, M.; Corbera-Bellalta, M.; Magnano, L.; et al. PI3Kdelta inhibition reshapes follicular lymphoma-immune microenvironment cross talk and unleashes the activity of venetoclax. Blood Adv. 2020, 4, 4217-4231. [CrossRef] [PubMed]

44. Davids, M.S.; Roberts, A.W.; Seymour, J.F.; Pagel, J.M.; Kahl, B.S.; Wierda, W.G.; Puvvada, S.; Kipps, T.J.; Anderson, M.A.; Salem, A.H.; et al. Phase I first-in-human study of venetoclax in patients with relapsed or refractory non-Hodgkin lymphoma. J. Clin. Oncol. 2017, 35, 826-833. [CrossRef] [PubMed]

45. Schnotalle, P.; Koch, K.; Au-Yeung, R.K.H.; Reinke, S.; Winter, K.; Loeffler, M.; Braumann, U.-D.; Klapper, W. T-cell clustering in neoplastic follicles of follicular lymphoma. Cancer Microenviron. 2018, 11, 135-140. [CrossRef] [PubMed]

46. Lee, C.G.; Das, B.; Lin, T.L.; Grimes, C.; Zhang, X.; Lavezzi, T.; Huang, L.; Cole, J.; Yau, L.; Li, L. A rare fraction of drug-resistant follicular lymphoma cancer stem cells interacts with follicular dendritic cells to maintain tumourigenic potential. Br. J. Haematol. 2012, 158, 79-90. [CrossRef] [PubMed]

47. Kagami, Y.; Jung, J.; Choi, Y.S.; Osumi, K.; Nakamura, S.; Morishima, Y.; Seto, M. Establishment of a follicular lymphoma cell line (FLK-1) dependent on follicular dendritic cell-like cell line HK. Leukemia 2001, 15, 148-156. [CrossRef] [PubMed]

48. Matas-Cespedes, A.; Rodriguez, V.; Kalko, S.G.; Vidal-Crespo, A.; Rosich, L.; Casserras, T.; Balsas, P.; Villamor, N.; Giné, E.; Campo, E.; et al. Disruption of Follicular Dendritic Cells-Follicular Lymphoma Cross-talk by the Pan-PI3K Inhibitor BKM120 (Buparlisib). Clin. Cancer Res. 2014, 20, 3458-3471. [CrossRef]

49. Amé-Thomas, P.; Hajjami, H.M.-E.; Monvoisin, C.; Jean, R.; Monnier, D.; Caulet-Maugendre, S.; Guillaudeux, T.; Lamy, T.; Fest, T.; Tarte, K. Human mesenchymal stem cells isolated from bone marrow and lymphoid organs support tumor B-cell growth: Role of stromal cells in follicular lymphoma pathogenesis. Blood 2007, 109, 693-702. [CrossRef]

50. Lwin, T.; Crespo, L.A.; Wu, A.; Dessureault, S.; Shu, H.B.; Moscinski, L.C.; Sotomayor, E.; Dalton, W.S.; Tao, J. Lymphoma cell adhesion-induced expression of B cell-activating factor of the TNF family in bone marrow stromal cells protects non-Hodgkin's B lymphoma cells from apoptosis. Leukemia 2009, 23, 170-177. [CrossRef]

51. Dubey, L.K.; Lebon, L.; Mosconi, I.; Yang, C.-Y.; Scandella, E.; Ludewig, B.; Luther, S.A.; Harris, N.L. Lymphotoxin-dependent B cell-Frc crosstalk promotes de novo follicle formation and antibody production following intestinal helminth infection. Cell Rep. 2016, 15, 1527-1541. [CrossRef] [PubMed]

52. Gregory, J.L.; Walter, A.; Alexandre, Y.O.; Hor, J.L.; Liu, R.; Ma, J.Z.; Devi, S.; Tokuda, N.; Owada, Y.; Mackay, L.K.; et al. Infection programs sustained lymphoid stromal cell responses and shapes lymph node remodeling upon secondary challenge. Cell Rep. 2017, 18, 406-418. [CrossRef]

53. Di Ianni, M.; Del Papa, B.; De Ioanni, M.; Moretti, L.; Bonifacio, E.; Cecchini, D.; Sportoletti, P.; Falzetti, F.; Tabilio, A. Mesenchymal cells recruit and regulate T regulatory cells. Exp. Hematol. 2008, 36, 309-318. [CrossRef]

54. Guilloton, F.; Caron, G.; Ménard, C.; Pangault, C.; Amé-Thomas, P.; Dulong, J.; Amé-Thomas, P.; Flecher, E.; Fest, T.; Tarte, K. Mesenchymal stromal cells orchestrate follicular lymphoma cell niche through the CCL2-dependent recruitment and polarization of monocytes. Blood 2012, 119, 2556-2567. [CrossRef] [PubMed]

55. Gregoire, M.; Guilloton, F.; Pangault, C.; Mourcin, F.; Sok, P.; Latour, M.; Amé-Thomas, P.; Flecher, E.; Fest, T.; Tarte, K. Neutrophils trigger a NF-kappaB dependent polarization of tumor-supportive stromal cells in germinal center B-cell lymphomas. Oncotarget 2015, 6, 16471-16487. [CrossRef]

56. Pandey, S.; Mourcin, F.; Marchand, T.; Nayar, S.; Guirriec, M.; Pangault, C.; Monvoisin, C.; Amé-Thomas, P.; Guilloton, F.; Dulong, J.; et al. IL-4/CXCL12 loop is a key regulator of lymphoid stroma function in follicular lymphoma. Blood 2017, 129, 2507-2518. [CrossRef]

57. Staiger, A.M.; Duppel, J.; Dengler, M.A.; Van Der Kuip, H.; Vöhringer, M.C.; Aulitzky, W.E.; Rosenwald, A.; Ott, G.; Horn, H. An analysis of the role of follicular lymphoma-associated fibroblasts to promote tumor cell viability following drug-induced apoptosis. Leuk. Lymphoma 2017, 58, 1922-1930. [CrossRef]

58. Sakamoto, A.; Kunou, S.; Shimada, K.; Tsunoda, M.; Aoki, T.; Iriyama, C.; Tomita, A.; Nakamura, S.; Hayakawa, F.; Kiyoi, H. Pyruvate secreted from patient-derived cancer-associated fibroblasts supports survival of primary lymphoma cells. Cancer Sci. 2019, 110, 269-278. [CrossRef] 
59. Fazilleau, N.; Mark, L.; McHeyzer-Williams, L.J.; McHeyzer-Williams, M.G. Follicular helper T cells: Lineage and location. Immunity 2009, 30, 324-335. [CrossRef]

60. Amé-Thomas, P.; Le Priol, J.; Yssel, H.; Caron, G.; Pangault, C.; Jean, R.; Martin, N.; Marafioti, T.; Gaulard, P.; Lamy, T.; et al. Characterization of intratumoral follicular helper $\mathrm{T}$ cells in follicular lymphoma: Role in the survival of malignant B cells. Leukemia 2012, 26, 1053-1063. [CrossRef]

61. Rawal, S.; Chu, F.; Zhang, M.; Park, H.J.; Nattamai, D.; Kannan, S.; Sharma, R.; Delgado, D.; Chou, T.; Lin, H.Y.; et al. Cross talk between follicular Th cells and tumor cells in human follicular lymphoma promotes immune evasion in the tumor microenvironment. J. Immunol. 2013, 190, 6681-6693. [CrossRef]

62. Pangault, C.; Ame-Thomas, P.; Ruminy, P.; Rossille, D.; Caron, G.; Baia, M.; De Vos, J.; Roussel, M.; Monvoisin, C.; Lamy, T.; et al. Follicular lymphoma cell niche: Identification of a preeminent IL-4-dependent T(FH)-B cell axis. Leukemia 2010, 24, 2080-2089. [CrossRef] [PubMed]

63. Townsend, W.; Pasikowska, M.; Yallop, D.; Phillips, E.H.; Patten, P.; Salisbury, J.R.; Marcus, R.; Pepper, A.; Devereux, S. The architecture of neoplastic follicles in follicular lymphoma; analysis of the relationship between the tumor and follicular helper $\mathrm{T}$ cells. Haematologica 2020, 105, 1593-1603. [CrossRef] [PubMed]

64. Lüthje, K.; Kallies, A.; Shimohakamada, Y.; Belz, G.T.; Light, A.; Tarlinton, D.M.; Nutt, S.L. The development and fate of follicular helper T cells defined by an IL-21 reporter mouse. Nat. Immunol. 2012, 13, 491-498. [CrossRef]

65. Amé-Thomas, P.; Hoeller, S.; Artchounin, C.; Misiak, J.; Braza, M.S.; Jean, R.; Priol, J.L.; Monvoisin, C.; Martin, N.; Gaulard, P.; et al. CD10 delineates a subset of human IL-4 producing follicular helper T cells involved in the survival of follicular lymphoma B cells. Blood 2015, 125, 2381-2385. [CrossRef]

66. Dheilly, E.; Battistello, E.; Katanayeva, N.; Sungalee, S.; Michaux, J.; Duns, G.; Wehrle, S.; Sordet-Dessimoz, J.; Mina, M.; Racle, J.; et al. Cathepsin S regulates antigen processing and T cell activity in non-Hodgkin lymphoma. Cancer Cell 2020, 37, 674-689. [CrossRef]

67. Schuster, S.J.; Svoboda, J.; Chong, E.A.; Nasta, S.D.; Mato, A.R.; Anak, Ö.; Brogdon, J.L.; Pruteanu-Malinici, I.; Bhoj, V.; Landsburg, D.; et al. Chimeric antigen receptor T cells in refractory B-cell lymphomas. N. Engl. J. Med. 2017, 377, 2545-2554. [CrossRef]

68. Chong, E.A.; Ruella, M.; Schuster, S.J. Lymphoma Program Investigators at the University of Pennsylvania. Five-year outcomes for refractory B-cell lymphomas with CAR T-cell therapy. N. Engl. J. Med. 2021, 384, 673-674. [CrossRef]

69. Neelapu, S.S.; Locke, F.L.; Bartlett, N.L.; Lekakis, L.J.; Miklos, D.B.; Jacobson, C.A.; Braunschweig, I.; Oluwole, O.O.; Siddiqi, T.; Lin, Y.; et al. Axicabtagene ciloleucel CAR T-cell therapy in refractory large B-cell lymphoma. N. Engl. J. Med. 2017, 377, 2531-2544. [CrossRef]

70. Locke, F.L.; Ghobadi, A.; Jacobson, C.A.; Miklos, D.B.; Lekakis, L.J.; Oluwole, O.O.; Lin, Y.; Braunschweig, I.; Hill, B.T.; Timmerman, J.M.; et al. Long-term safety and activity of axicabtagene ciloleucel in refractory large B-cell lymphoma (ZUMA-1): A single-arm, multicentre, phase 1-2 trial. Lancet Oncol. 2019, 20, 31-42. [CrossRef]

71. Bunse, M.; Pfeilschifter, J.; Bluhm, J.; Zschummel, M.; Joedicke, J.J.; Wirges, A.; Stark, H.; Kretschmer, V.; Chmielewski, M.; Uckert, W.; et al. CXCR5 CAR-T cells simultaneously target B cell non-Hodgkin's lymphoma and tumor-supportive follicular T helper cells. Nat. Commun. 2021, 12. [CrossRef] [PubMed]

72. Chu, F.; Li, H.S.; Liu, X.; Cao, J.; Ma, W.; Ma, Y.; Weng, J.; Zhu, Z.; Cheng, X.; Wang, Z.; et al. CXCR5(+)CD8(+) T cells are a distinct functional subset with an antitumor activity. Leukemia 2019, 33, 2640-2653. [CrossRef] [PubMed]

73. Rolf, J.; Bell, S.E.; Kovesdi, D.; Janas, M.L.; Soond, D.R.; Webb, L.M.; Santinelli, S.; Saunders, T.; Hebeis, B.; Killeen, N.; et al. Phosphoinositide 3-kinase activity in T cells regulates the magnitude of the germinal center reaction. J. Immunol. 2010, 185, 4042-4052. [CrossRef]

74. Hilchey, S.P.; De, A.; Rimsza, L.M.; Bankert, R.B.; Bernstein, S.H. Follicular lymphoma intratumoral CD4 + CD25 + GITR + regulatory $\mathrm{T}$ cells potently suppress CD3/CD28-costimulated autologous and allogeneic CD8 + CD25- and CD4 + CD25- T cells. J. Immunol. 2007, 178, 4051-4061. [CrossRef] [PubMed]

75. Hilchey, S.P.; Rosenberg, A.F.; Hyrien, O.; Secor-Socha, S.; Cochran, M.R.; Brady, M.T.; Wang, J.-C.; Sanz, I.; Burack, W.R.; Quataert, S.A.; et al. Follicular lymphoma tumor-infiltrating T-helper $(\mathrm{T}(\mathrm{H})$ ) cells have the same polyfunctional potential as normal nodal $\mathrm{T}(\mathrm{H})$ cells despite skewed differentiation. Blood 2011, 118, 3591-3602. [CrossRef]

76. Nedelkovska, H.; Rosenberg, A.F.; Hilchey, S.P.; Hyrien, O.; Burack, W.R.; Quataert, S.A.; Baker, C.M.; Azadniv, M.; Welle, S.L.; Ansell, S.M.; et al. Follicular lymphoma tregs have a distinct transcription profile impacting their migration and retention in the malignant lymph node. PLoS ONE 2016, 11, e0155347. [CrossRef]

77. Le, K.-S.; Thibult, M.-L.; Just-Landi, S.; Pastor, S.; Gondois-Rey, F.; Granjeaud, S.; Broussais, F.; Bouabdallah, R.; Colisson, R.; Caux, C.; et al. Follicular B lymphomas generate regulatory T cells via the ICOS/ICOSL pathway and are susceptible to treatment by anti-ICOS/ICOSL therapy. Cancer Res. 2016, 76, 4648-4660. [CrossRef]

78. Boice, M.; Salloum, D.; Mourcin, F.; Sanghvi, V.; Amin, R.; Oricchio, E.; Jiang, M.; Mottok, A.; Denis-Lagache, N.; Ciriello, G.; et al. Loss of the HVEM tumor suppressor in lymphoma and restoration by modified CAR-T cells. Cell 2016, 167, 405-418. [CrossRef] [PubMed]

79. Watanabe, N.; Gavrieli, M.; Sedy, J.R.; Yang, J.; Fallarino, F.; Loftin, S.K.; Hurchla, M.A.; Zimmerman, N.; Sim, J.; Zang, X.; et al. BTLA is a lymphocyte inhibitory receptor with similarities to CTLA-4 and PD-1. Nat. Immunol. 2003, 4, 670-679. [CrossRef] 
80. Mintz, M.A.; Felce, J.H.; Chou, M.Y.; Mayya, V.; Xu, Y.; Shui, J.-W.; An, J.; Li, Z.; Marson, A.; Okada, T.; et al. The HVEM-BTLA axis restrains $\mathrm{T}$ cell help to germinal center $\mathrm{B}$ cells and functions as a cell-extrinsic suppressor in lymphomagenesis. Immunity 2019, 51, 310-323. [CrossRef]

81. Cheung, K.-J.J.; Johnson, N.A.; Affleck, J.G.; Severson, T.; Steidl, C.; Ben-Neriah, S.; Schein, J.; Morin, R.D.; Moore, R.; Shah, S.P.; et al. Acquired TNFRSF14 mutations in follicular lymphoma are associated with worse prognosis. Cancer Res. 2010, 70, 9166-9174. [CrossRef]

82. Crotty, S. T follicular helper cell differentiation, function, and roles in disease. Immunity 2014, 41, 529-542. [CrossRef]

83. Kotsiou, E.; Okosun, J.; Besley, C.; Iqbal, S.; Matthews, J.; Fitzgibbon, J.; Gribben, J.G.; Davies, J.K. TNFRSF14 aberrations in follicular lymphoma increase clinically significant allogeneic T-cell responses. Blood 2016, 128, 72-81. [CrossRef] [PubMed]

84. Lackraj, T.; Goswami, R.; Kridel, R. Pathogenesis of follicular lymphoma. Best Pract. Res. Clin. Haematol. 2018, 31, 2-14. [CrossRef] [PubMed]

85. Carreras, J.; Lopez-Guillermo, A.; Kikuti, Y.Y.; Itoh, J.; Masashi, M.; Ikoma, H.; Tomita, S.; Hiraiwa, S.; Hamoudi, R.; Rosenwald, A.; et al. High TNFRSF14 and low BTLA are associated with poor prognosis in Follicular Lymphoma and in Diffuse Large B-cell Lymphoma transformation. J. Clin. Exp. Hematop. 2019, 59, 1-16. [CrossRef] [PubMed]

86. Hutchings, M.; Lugtenburg, P.; Mous, R.; Clausen, M.R.; Chamuleau, M.; Linton, K.; Rule, S.; Lopez, J.S.; Oliveri, R.S.; DeMarco, D.; et al. Epcoritamab (GEN3013; DuoBody-CD3xCD20) to induce complete response in patients with relapsed/refractory B-cell non-Hodgkin lymphoma (B-NHL): Complete dose escalation data and efficacy results from a phase I/II trial. J. Clin. Oncol. 2020, 38. [CrossRef]

87. Van der Horst, H.J.; de Jonge, A.V.; Hiemstra, I.H.; Gelderloos, A.T.; Berry, D.R.A.I.; Hijmering, N.J.; van Essen, H.F.; de Jong, D.; Chamuleau, M.E.D.; Zweegman, S.; et al. Epcoritamab induces potent anti-tumor activity against malignant B-cells from patients with DLBCL, FL and MCL, irrespective of prior CD20 monoclonal antibody treatment. Blood Cancer J. 2021, 11. [CrossRef]

88. Tuscano, J.M.; Maverakis, E.; Groshen, S.; Tsao-Wei, D.; Luxardi, G.; Merleev, A.A.; Beaven, A.; DiPersio, J.F.; Popplewell, L.; Chen, R.; et al. A phase I study of the combination of rituximab and ipilimumab in patients with relapsed/refractory B-cell lymphoma. Clin. Cancer Res. 2019, 25, 7004-7013. [CrossRef]

89. Cao, R.; Wang, L.; Wang, H.; Xia, L.; Erdjument-Bromage, H.; Tempst, P.; Jones, R.S.; Zhang, Y. Role of histone H3 lysine 27 methylation in Polycomb-group silencing. Science 2002, 298, 1039-1043. [CrossRef]

90. Arvey, A.; van der Veeken, J.; Samstein, R.M.; Feng, Y.; Stamatoyannopoulos, J.A.; Rudensky, A.Y. Inflammation-induced repression of chromatin bound by the transcription factor Foxp3 in regulatory T cells. Nat Immunol. 2014, 15, 580-587. [CrossRef]

91. Goswami, S.; Apostolou, I.; Zhang, J.; Skepner, J.; Anandhan, S.; Zhang, X.; Xiong, L.; Trojer, P.; Aparicio, A.; Subundhi, S.K.; et al. Modulation of EZH2 expression in T cells improves efficacy of anti-CTLA-4 therapy. J. Clin. Investig. 2018, 128, $3813-3818$. [CrossRef] [PubMed]

92. Morschhauser, F.; Tilly, H.; Chaidos, A.; McKay, P.; Phillips, T.; Assouline, S.; Batlevi, C.L.; Cambell, P.; Ribrag, V.; Damaj, G.L.; et al. Tazemetostat for patients with relapsed or refractory follicular lymphoma: An open-label, single-arm, multicentre, phase 2 trial. Lancet Oncol. 2020, 21, 1433-1442. [CrossRef]

93. Bödör, C.; O’Riain, C.; Wrench, D.; Matthews, J.; Iyengar, S.; Tayyib, H.; Calaminchi, M.; Clear, A.; Iqbal, S.; Quentmeier, H.; et al. EZH2 Y641 mutations in follicular lymphoma. Leukemia 2011, 25, 726-729. [CrossRef] [PubMed]

94. Guo, S.; Chan, J.K.; Iqbal, J.; McKeithan, T.; Fu, K.; Meng, B.; Pan, Y.; Cheuk, W.; Luo, D.; Wang, R.; et al. EZH2 mutations in follicular lymphoma from different ethnic groups and associated gene expression alterations. Clin. Cancer Res. 2014, 20, 3078-3086. [CrossRef] [PubMed]

95. Wang, D.; Quiros, J.; Mahuron, K.; Pai, C.C.; Ranzani, V.; Young, A.; Silveria, S.; Harwin, T.; Abnousian, A.; Pagani, M.; et al. Targeting EZH2 Reprograms Intratumoral Regulatory T Cells to Enhance Cancer Immunity. Cell Rep. 2018, 23, 3262-3274. [CrossRef] [PubMed]

96. Chellappa, S.; Kushekhar, K.; Munthe, L.A.; Tjonnfjord, G.E.; Aandahl, E.M.; Okkenhaug, K.; Tasken, K. The PI3K p110delta Isoform Inhibitor Idelalisib Preferentially Inhibits Human Regulatory T Cell Function. J. Immunol. 2019, 202, 1397-1405. [CrossRef]

97. Leonard, J.P.; Trneny, M.; Izutsu, K.; Fowler, N.H.; Hong, X.; Zhu, J.; Zhang, H.; Offner, F.; Scheliga, A.; Nowakowski, G.S.; et al AUGMENT: A phase III study of lenalidomide plus rituximab versus placebo plus rituximab in relapsed or refractory indolent lymphoma. J. Clin. Oncol. 2019, 37, 1188-1199. [CrossRef] [PubMed]

98. Chiu, H.; Trisal, P.; Bjorklund, C.; Carrancio, S.; Toraño, E.G.; Guarinos, C.; Papazoglou, D.; Hagner, P.R.; Beldi-Ferchiou, A.; Tarte, K.; et al. Combination lenalidomide-rituximab immunotherapy activates anti-tumour immunity and induces tumour cell death by complementary mechanisms of action in follicular lymphoma. Br. J. Haematol. 2019, 185, 240-253. [CrossRef]

99. Josefsson, S.E.; Beiske, K.; Blaker, Y.N.; Førsund, M.S.; Holte, H.; Østenstad, B.; Kimby, E.; Köksal, H.; Wälchli, S.; Bai, B.; et al. TIGIT and PD-1 mark intratumoral T cells with reduced effector function in B-cell non-Hodgkin lymphoma. Cancer Immunol. Res. 2019, 7, 355-362. [CrossRef]

100. Josefsson, S.E.; Huse, K.; Kolstad, A.; Beiske, K.; Pende, D.; Steen, C.B.; Inderberg, E.M.; Lingjærde, O.C.; Østenstad, B.; Smeland, E.B.; et al. T cells expressing checkpoint receptor TIGIT are enriched in follicular lymphoma tumors and characterized by reversible suppression of T-cell receptor signaling. Clin. Cancer Res. 2018, 24, 870-881. [CrossRef] 
101. Yang, Z.-Z.; Kim, H.J.; Wu, H.; Jalali, S.; Tang, X.; Krull, J.E.; Ding, W.; Novak, A.J.; Ansell, S.M. TIGIT expression is associated with T-cell suppression and exhaustion and predicts clinical outcome and anti-PD-1 response in follicular lymphoma. Clin. Cancer Res. 2020, 26, 5217-5231. [CrossRef] [PubMed]

102. Yang, Z.-Z.; Kim, H.J.; Villasboas, J.C.; Chen, Y.-P.; Price-Troska, T.; Jalali, S.; Wilson, M.; Novak, A.J.; Ansell, S.M. Expression of LAG-3 defines exhaustion of intratumoral PD-1(+) T cells and correlates with poor outcome in follicular lymphoma. Oncotarget 2017, 8, 61425-61439. [CrossRef] [PubMed]

103. Yang, Z.-Z.; Kim, H.J.; Villasboas, J.C.; Price-Troska, T.; Jalali, S.; Wu, H.; Luchtel, R.A.; Polley, M.-Y.; Novak, A.J.; Ansell, S.M. Mass cytometry analysis reveals that specific intratumoral CD4(+) T cell subsets correlate with patient survival in follicular lymphoma. Cell Rep. 2019, 26, 2178-2193. [CrossRef] [PubMed]

104. Pangault, C.; Amé-Thomas, P.; Rossille, D.; Dulong, J.; Caron, G.; Nonn, C.; Chatonnet, F.; Desmots, F.; Launay, V.; Lamy, T.; et al. Integrative analysis of cell crosstalk within follicular lymphoma cell niche: Towards a definition of the FL supportive synapse. Cancers 2020, 12, 2865. [CrossRef] 